MACIEJ BUKOWSKI, PIOTR KORYŚ, CECYLIA LESZCZYŃSKA, MACIEJ TYMIŃSKI*

Wydział Nauk Ekonomicznych Uniwersytetu Warszawskiego

\title{
ROZWÓJ REGIONALNY ZIEM POLSKICH POD ZABORAMI. PORÓWNANIE POZIOMU PRODUKTU BRUTTO PER CAPITA NA DZISIEJSZYCH TERENACH POLSKI NA PRZEŁOMIE XIX I XX W. (WYNIKI PIERWSZYCH ESTYMACJI)**
}

Zarys treści: Przedmiotem artykułu jest rekonstrukcja historycznego produktu krajowego (PKB) ziem polskich na przełomie XIX i XX w. Jest to pierwszy w polskiej historiografii gospodarczej spójny szacunek PKB dla poszczególnych dzielnic zaborczych oraz całości ziem polskich w latach 1900 i 1910, w podwójnym ujęciu - w granicach z przełomu XIX i XX w. oraz w granicach współczesnych. Badanie oparto na szerokiej bazie statystycznej, w obliczeniach dochodów na poziomie dzielnic i PKB ogółem zastosowano metodę produktowa oraz bottom-up, część obliczeń przeprowadzono z wykorzystaniem regresji liniowej. Artykuł składa się z pięciu podrozdziałów: omówienie stanu badań, zakres terytorialny badania, źródła, metoda, wyniki i ich interpretacja. W zakończeniu przedstawiono wnioski i dezyderaty dotyczace dalszych prac w tej dziedzinie.

The content outline: The article presents a reconstruction of historic gross domestic product (GDP) in the Polish lands at the turn of the twentieth century. This is the first in the Polish economic historiography comprehensive GDP estimate for individual partitions and the whole Polish territory in 1900 and 1910, in a double approach: within the frontiers at the turn of the nineteenth century and within the present ones. The study has been based on a broad statistical basis, the calculations of income on the level of partitions and total GDP have been performed with the output method and bottom-up

* Maciej Bukowski - WNE UW; Piotr Koryś - WNE UW i IWM (prace nad artykułem realizowane były w trakcie pobytu autora w Instytucie Nauk o Człowieku, IWM, w Wiedniu, w ramach stypendium im. B. Geremka, współfinansowanego przez Ministerstwo Nauki i Szkolnictwa Wyższego RP); Cecylia Leszczyńska - WNE UW; Maciej Tymiński - WNE UW.

** Opracowanie powstało dzięki wsparciu NCN w ramach grantu 2012/07/B/ HS4/00451 realizowanego na WNE UW. 
method, part of the computations has been made with the use of simple linear regression. The article is divided into five parts: 1) a description of the present state of research, 2) a territorial scope of the study, 3) sources, 4) methods, 5) results and their interpretation. The closing part contains conclusions and proposition for further research in the field.

Słowa kluczowe: rozwój gospodarczy, rozwój regionalny, PKB, Polska w XIX w.

Keywords: economic development, regional development, GDP, Poland in the nineteenth century

\section{Wstęp}

Ważnym nurtem badań we współczesnej historii gospodarczej jest rekonstrukcja historycznych rachunków narodowych. Coraz częściej podejmowane są też wysiłki, by miary te szacować na poziomie regionalnym. Badania tego rodzaju pozwalają na lepsze zrozumienie powodów, dla których niektóre regiony weszły na ścieżkę szybkiego rozwoju, podczas gdy inne pozostawały zacofane.

Jeśli idzie o ziemie polskie badań tego rodzaju, jak dotąd, nie prowadzono, co wynikało m.in. ze szczątkowej postaci szacunków historycznego PKB. Niniejszy artykuł wypełnia tę lukę w odniesieniu do przełomu XIX i XX w. Zaprezentowane w nim zestawienia sa pierwsza w historiografii gospodarczej próbą spójnych szacunków rachunków regionalnych dla lat 1900 i 1910 . Ich przeprowadzenie wymagało pokonania kilku istotnych barier. Pierwszą jest skapy i nierównomierny zasób historycznych statystyk, który powoduje konieczność stosowania mieszanej metodologii przy rekonstrukcji danych historycznych. Kolejnym problemem jest zakres terytorialny tego co nazywamy ziemiami polskimi w XIX w. Można tu przyjąć kryterium historyczno-polityczne (terytorium Rzeczypospolitej Obojga Narodów z końca XVIII w.), etniczno-narodowościowo-językowe (obszary zamieszkane przez zwarte skupiska ludności polskiej) bądź terytorium II Rzeczypospolitej. Ze względów porównawczych (ze współczesnym terytorium Polski) w badaniach historycznych uwzględniane były także prowincje niemieckie (Dolny Śląsk, Pomorze Zachodnie, Warmia i Mazury), które znalazły się w granicach Polski po II wojnie światowej. W niniejszym artykule obliczenia przeprowadziliśmy dla jednostek administracyjnych średniego szczebla trzech dzielnic zaborczych (Królestwo Polskie, Galicja, zabór pruski), porównawczo dodając szacunki dla rejencji niemieckich, które znalazły się w Polsce po 1945 r. Rozwiązanie to ma ważną zaletę polegająca na tym, że może 
stanowić punkt wyjścia dla przyszłych analiz regionalnego PKB zarówno dla terytorium Polski w XX w. (II Rzeczpospolita, Polska Ludowa), jak i dla Polski w okresie przedrozbiorowym.

Rekonstrukcje polskiego PKB jednocześnie w wymiarze regionalnym i ogólnokrajowym, odniesione do terytorium obecnej Polski, nie były do tej pory przedmiotem prac naukowych. Najczęściej przywoływane przez historyków oszacowania Angusa Maddisona sa ekstrapolacją dla terytorium współczesnej Polski danych dotyczących Galicji, co z racji niskiego poziomu rozwoju tego regionu prowadzi do zaniżenia wartości dla całego kraju. Mniej znane w literaturze światowej są szacunki Anny i Grzegorza Wójtowiczów ${ }^{1}$, dotyczą one terytorium współczesnej Polski, lecz nie zostały przedstawione wraz z jasno wyłożoną metodologia. Krytyczne omówienie tych szacunków zostanie przedstawione dalej.

Przeprowadzony przez nas szacunek bazuje na bardzo szerokiej bazie źródłowej. Stanowią ją statystyki polskie i zagraniczne dotyczące gospodarki i społeczeństwa, studia zagranicznych badaczy dotyczące PKB oraz prace polskich historyków poświęcone gospodarce poszczególnych zaborów albo wybranych dziedzin gospodarki². Stanowią one źródło cennych danych i informacji oraz interpretacji.

Artykuł składa się z pięciu podrozdziałów. Pierwszy przedstawia stan badań, drugi charakteryzuje szczegółowo zakres terytorialny przeprowadzonego przez nas badania, trzeci opisuje źródła pochodzenia wykorzystanych w badaniu danych, czwarty przedstawia metodę, a piaty wyniki naszych obliczeń i ich interpretację. W zakończeniu przedstawiamy wnioski i dezyderaty dotyczące dalszych prac w tej dziedzinie.

\section{Stan badań}

Badania służące odtworzeniu poziomu PKB w mniej lub bardziej odległych epokach mają relatywnie krótką historię, rozwijać się bowiem zaczęły dopiero w ostatnich dekadach XX w. ${ }^{3}$ Dodać należy, że kategoria

${ }^{1}$ G. Wójtowicz, Trendy i ewolucja. Dzieje gospodarcze ziem polskich, Warszawa 2006; A. Wójtowicz, G. Wójtowicz, Dlaczego nie jesteśmy bogaci? Dystans gospodarki polskiej do zachodnioeuropejskiej, Warszawa 2009.

${ }^{2}$ W grupie badaczy tych zagadnień, którzy w swoich pracach szerzej przywoływali dane ilościowe, wymienić można m.in.: Ireneusza Ihnatowicza, Andrzeja Jezierskiego, Ryszarda Kołodziejczyka, Witolda Kulę, Czesława Łuczaka, Jerzego Łukasiewicza, Irenę Pietrzak-Pawłowską czy Wiesława Pusia.

${ }^{3}$ Mamy na tu na myśli badania zakrojone na szeroką skalę, dotyczące długich okresów oraz wielu państw. Jednostkowe próby szacowania PKB podejmowane były oczywiście wcześniej. 
„produktu” w sensie bliskim współczesnemu zaczęła być szacowana w latach 30. XX w. W Wielkiej Brytanii pionierskie analizy PNB przedstawił w 1932 r. Colin Clark ${ }^{4}$. Dwa lata wcześniej szacunki dochodu społecznego dla wybranych państw sporządził Dresdner Bank ${ }^{5}$. W Stanach Zjednoczonych poziom dochodu narodowego stanowiącego „część końcowego produktu gospodarki” zawierał raport Simona Kuznetsa z 1934 r., przygotowany dla Senatu USA ${ }^{6}$. W Polsce szacunki dochodu społecznego dla końca lat 20. i początku lat 30. XX w. przedstawili Michał Kalecki i Ludwik Landau oraz Bohdan Dederko ${ }^{7}$. Wartości produktu krajowego i dochodu narodowego dla kilku państw (na podstawie danych urzędowych) opublikował w 1945 r. rocznik Ligi Narodów ${ }^{8}$.

Po II wojnie światowej prowadzenie rachunków narodowych weszło do zadań państwowych urzędów statystycznych. Pojawiły się też autorskie oszacowania historycznego dochodu narodowego i jego dynamiki (sięgały one końca XIX i początków XX w.) ${ }^{9}$. Miały one związek z silnie obecnymi w ówczesnej teorii ekonomii badaniami długookresowego rozwoju gospodarczego oraz podziału dochodu narodowego.

Szerokie badania porównawcze historycznego PKB w ujęciu regionalnym, narodowym i międzynarodowym zaczęły być rozwijane od lat 70. XX w., stając się jednym z ważniejszych obszarów nowej historii gospodarczej i tzw. ekonomii historycznej. Zainteresowanie nimi

${ }^{4}$ C. Clark, The National Income, 1924-31, London 1932; tenże, National Income and Outlay, London 1937.

${ }^{5}$ Dresdner Bank, The Economic Forces of the World, Berlin 1930.

${ }^{6}$ Jak pisze Dirk Philipsen, raport Kuznetsa „wyzwolił USA od tyranii ekonomicznej ignorancji”; tenże, The Little Big Number. How GDP Came to Rule the World and What to do about It, Princeton 2015, s. 10-11. Książka ta jest krytyka postawy fetyszyzowania PKB we współczesnej ekonomii.

${ }^{7}$ M. Kalecki, L. Landau, Szacunek dochodu społecznego w r. 1929, Warszawa 1934; ciż, Dochód społeczny w r. 1933 i podstawy badań periodycznych nad zróżnicowaniem dochodu, Warszawa 1935; B. Dederko, Dochód społeczny Polski, „Kwartalnik Statystyczny" 1930, z. 2, s. 135-150; L. Landau, Gospodarka światowa. Produkcja $i$ dochód społeczny $w$ liczbach, Warszawa 1939.

8 Statistical Yearbook of the League of Nations 1942/44, Geneva 1945.

${ }_{9}$ M.in. C. Clark, The Conditions of Economic Progress, London 1940, 1951 i 1957. Na początku lat 50. XX w. wyniki badań dochodu narodowego sięgające lat 70. XIX w. według możliwie spójnej metodologii przedstawiali na łamach „The Review of Income and Wealth": S. Kuznets, Long-Term Changes in the National Income of the United States since 1870 (1952, t. 2, s. 29-241); J.B. Jefferys, D. Walters, National Income and Expenditure of the United Kingdom, 1870-1952 (1955, t. 5, s. 1-40); P. Jostock, The Long-Term Growth of National Income in Germany (tamże, s. 79-122); K. Bjerke, The National Product of Denmark 1870-1952 (tamże, s. 123-151); A. Eckstein, National Income and Capital Formation in Hungary, 1900-1950 (tamże, s. 152-223); Y. Yamada, Notes on Income Growth and Rate of Saving in Japan (tamże, s. 224-242). 
ekonomistów i historyków wynikało z kilku okoliczności. Niewątpliwie ważne były aspekty poznawcze, a więc dążenie do określenia poziomu i dynamiki gospodarczej państw, regionów, kontynentów w układzie sekularnym. Miara produktowa, choć mająca szereg ułomności, pozwalała na kwantytatywne analizy porównawcze, zarówno w czasie, jak i przestrzeni ${ }^{10}$. Odtworzenie wartości PKB umożliwiało zastosowanie w badaniach historycznych współczesnych wskaźników, w których kategoria PKB jest wykorzystywana ${ }^{11}$. Kolejną ważną okolicznością było dążenie do odpowiedzi na pytania o historyczne nierówności rozwojowe między państwami. Chodziło m.in. o kwestię pogłębiania się bądź niwelowania tych dysproporcji w epoce przemysłowej i postprzemysłowej. W kontekście procesów globalizacyjnych zachodzących od lat 70 . XX w. ważne stało się też poszukiwanie - poprzez historyczne analogie - ich natury i konsekwencji ekonomiczno-społecznych. Analizy globalizacji z lat 1870-1914 były jednym z argumentów w dyskusji dotyczącej konsekwencji liberalizacji gospodarczej w skali międzynarodowej: czy prowadziła ona do wyrównywania poziomu PKB, czy też raczej pogłębiania różnic ${ }^{12}$. Badania wskazywały - jeśli idzie o kraje rolnicze lub półprzemysłowe - raczej na dywergencję, konwergencja występowała natomiast $\mathrm{w}$ przypadku państw przemysłowych. Problem ten stał się przedmiotem wielu kolejnych badań, prowadzących często do sprzecznych wniosków ${ }^{13}$.

Badania historycznego PKB były w różnym stopniu zaawansowane w poszczególnych krajach. Można przyjąć, że obecnie pozwalają one określić PKB (jego poziom, strukturę, podział) dla wszystkich państw zachodnich począwszy od połowy XIX w. ${ }^{14}$ Współczesne estymacje służą

${ }^{10}$ Dodajmy, że szerokie badania ilościowe stały się możliwe dzięki nowoczesnym technikom informatycznym, pozwalającym na przetwarzanie wielkich zbiorów danych.

${ }^{11}$ Dług publiczny do PKB, inwestycje do PKB, saldo obrotów handlowych do PKB itd.

12 R.C. Allen, The British Industrial Revolution in Global Perspective, Cambridge 2009; J.L. van Zanden, The Long Road to the Industrial Revolution. The European Economy in the Global Perspective, 1000-1800, Leiden 2009; D. Acemoglu, S. Johnson, J. Robinson, The Rise of Europe. Atlantic Trade, Institutional Change, and Economic Growth, „American Economic Review” 95, 2005, s. 546-575.

${ }_{13}$ Problemowi różnic między narodami poświęcona jest m.in. książka D.S. Landesa, Bogactwo i nędza narodów. Dlaczego jedni sa tak bogaci, a inni tak ubodzy, tłum. H. Jankowska, Warszawa 2000.

${ }^{14}$ Objęły one m.in. gospodarki europejskiego Południa: S. Fenoaltea, The Reconstruction of Historical National Accounts. The Case of Italy, „PSL Quarterly Review” 63, 2010, nr 252, s. 77-96; tenże, The Growth of the Italian Economy, 1861-1913. Preliminary Second-Generation Estimates, „European Review of Economic History” 2005, $\mathrm{nr}$ 9, s. 273-312; S. Broadberry, A. Klein, Aggregate and per capita GDP in Europe, 1870 
zasadniczo korygowaniu i uszczegółowianiu szacunków powstałych w ostatnim półwieczu bądź są elementem nowych analiz porównawczych, w tym w ujęciu regionalnym ${ }^{15}$. Istniejace luki dotyczą natomiast państw rozwijających się i gospodarek wschodzących, w tym Europy Środkowo-Wschodniej.

$\mathrm{W}$ ostatnich latach badania dotyczące naszego regionu posunęły się istotnie naprzód ${ }^{16}$. Nie dotyczy to niestety Polski. Badania polskiego PKB dla końca XIX i początku XX w. nie były dotąd prowadzone ${ }^{17}$.

-2000. Continental, Regional and National Data with Changing Boundaries, 27 X 2011, http://www.lse.ac.uk/economicHistory/pdf/Broadberry/EuroGDP2.pdf (5 VII 2016).

${ }_{15}$ M. Badia-Miró, J. Guilera, P. Lains, Regional Incomes in Portugal. Industrialisation, Integration and Inequality, 1890-1980, „Revista de Historia Económica” 30, 2012, nr 2, s. 225-244; P. Caruana-Galicia, Economic Development and Market Potential. European Regional Income Differentials, 1870-1913, London 2015, rozprawa doktorska, The London School of Economics and Political Science; N.F.R. Crafts, Regional GDP in Britain, 1871-1911. Some Estimates, „London School of Economics. Working Paper" 2004, nr 3; J. Martínez Galarraga, New Estimates of Regional GDP in Spain, 1860-1930, „Working Papers in Economics from Universitat de Barcelona. Recerca en Economia" 2007, nr 177; F. Geary, T. Stark, Examining Ireland's Post-Famine Economic Performance. The Distribution of Gross Domestic Product between the Countries of the United Kingdom, 1861-1911, „The Economic Journal” 2002, nr 112, s. 919-935; ciż, Regional GDP in the UK, 1861-1911. New Estimates, „The Economic History Review” 68, 2015, nr 1, s. 123-144. Większość tych autorów bazuje na metodzie Geary'ego-Starka, wykorzystujacej do szacowania regionalnego PKB produktywność przemysłu na poziomie krajowym, regionalną strukturę zatrudnienia oraz płace na poziomie sektorowym i regionalnym.

${ }^{16}$ Warto zwrócić uwagę na kilka prac dotyczących Rosji, Niemiec i Austrii, które sa istotne także dla Polski: P. Gregory, Russian National Income 1885-1913, Cambridge 1982; A. Markevich, Economic Development of the late Russian Empire in a Regional Perspective, 2014, SSRN: http://ssrn.com/abstract=2555273 (12 V 2016); Electronic Repository of Russian Historical Statistics, $18^{\text {th }}-21^{\text {st }}$ centuries, http://ristat.org/ (16 IV 2016); D.F. Good, The Economic Lag of Central and Eastern Europe. Income Estimates for the Habsburg Successor States, 1870-1910, „Journal of Economic History” 1994, nr 54, s. 869-891; D.F. Good, T. Ma, New Estimates of Income Levels in Central and Eastern Europe, 1870-1910, w: Von der Theoriezur Wirtschaftspolitik - ein Oesterreichischer Weg. Festschriftzum 65. Geburtstag von Erich Streissler, red. F. Baltzarek, F. Butschek, G. Tichy, Stuttgart 1998, s. 147-168; M.S. Schulze, Patterns of Growth and Stagnation in the Late Nineteenth Century Habsburg Economy, „European Review of Economic History" 2000, nr 4, s. 311-340; tenże, Reestimating Austrian GDP, 1870-1913. Methods and Sources, „Economic History Working Papers” 1997, $\mathrm{nr} 36$; tenże, Regional Income Dispersion and Market Potential in the Late Nineteenth Century Hapsburg Empire, „Working Papers” 2007, nr 106; P. Caruana-Galicia, German Regional GDP. Preliminary Land-Level LSE Estimates, 1871-1907, London 2011.

${ }^{17}$ Dotyczy to też okresu II Rzeczypospolitej, ale także Polski Ludowej, dla której nadal dysponujemy jedynie obliczeniami bazującymi na systemie MPS (Material Product System). 
W syntezach historyczno-ekonomicznych przywoływane są najczęściej szacunki sporządzone przez badaczy zagranicznych, które znalazły się w zestawieniach Angusa Maddisona ${ }^{18}$. Wiarygodność statystyk maddisonowskich w odniesieniu do Polski jest wątpliwa z dwóch zasadniczych powodów: po pierwsze, sa one ekstrapolacją obliczeń Davida Gooda i Tongshu Ma dotyczacych Galicji (jako jednego z regionów Austro-Węgier $)^{19}$; dane galicyjskie zostały potraktowane jako adekwatne dla pozostałych ziem polskich, dla których obliczeń nie przeprowadzono, opatrując to zastrzeżeniem o niskiej wiarygodności danych. Po drugie, metoda zastosowana przez Gooda i Ma spotkała się z krytyka innych badaczy ${ }^{20}$. Jeśli idzie o szacunki polskich badaczy dysponujemy jedynie obliczeniami Grzegorza i Anny Wójtowiczów. Zostały one jednak krytycznie ocenione przez Mikołaja Malinowskiego, który zarzucił im bardzo szczątkowe udokumentowanie użytej metody, a więc - pośrednio - niemożność ich replikacji ${ }^{21}$.

\section{Zakres geograficzny badania}

Określenie odpowiedniego obszaru badań dla ziem polskich jest z kilku względów utrudnione. Polskie granice przez ostatnie trzy stulecia podlegały częstym zmianom, co wiąże się z burzliwą historia kraju. Najpierw w XVIII w. miały miejsce rozbiory, w wyniku których państwo w ogóle zniknęło z mapy Europy, następnie na skutek wojen napoleońskich i Kongresu Wiedeńskiego powstało Księstwo Warszawskie i Królestwo Polskie, co ponownie zmieniło przebieg granic. Do tego decyzjami państw zaborczych województwa i ziemie dawnej Rzeczypospolitej zostały przecięte granicami nowych jednostek administracyjnych. Po I wojnie światowej wraz z powstaniem II Rzeczypospolitej układ granic ponownie uległ zmianie. Po raz kolejny przesunęły się one

18 A. Maddison, The World Economy. Historical Statistics, Development Centre of the Organisation for Economic Co-operation and Development, 2006.

${ }^{19}$ D.F. Good, dz. cyt.; D.F. Good, T. Ma, dz. cyt.; M.-S. Schulze, Patterns...; tenże, Reestimating...; tenże, Regional...

${ }^{20}$ Uwagi krytyczne zgłosił M.-S. Schulze, przedstawił też własne szacunki, które uznawane sa za bardziej wiarygodne; por. tenże, Patterns...

${ }^{21}$ Pisze on, że szacunki Wójtowicza są „zdecydowanie najsłabsze metodologicznie i warsztatowo ze wszystkich rekonstrukcji PKB w Polsce”. Wójtowicz nie wyjaśnił bądź wskazał ogólnikowo pochodzenie użytych danych, zadeklarował jedynie, że zostały one oparte na „szacunkach i obliczeniach własnych”; M. Malinowski, Zmierzyć zacofanie. Zestawienie najważniejszych szacunków materialnych standardów życia w Polsce przedprzemysłowej, RDSG, t. 76, 2016, s. 82-83. 
w wyniku ustaleń po II wojnie światowej. W tych okolicznościach określenie, jakie terytorium należy uważać za ziemie polskie jest niezwykle trudne. Dodajmy, że na przestrzeni tego okresu wielokrotne zmieniane były granice jednostek podziału administracyjnego najwyższego szczebla (odpowiednika województw), raczej stabilne były natomiast granice powiatów czy gmin.

Niniejszy artykuł przedstawia oszacowanie PKB per capita dla przełomu XIX i XX w. w ujęciu regionalnym dla trzech dzielnic zaborczych (Królestwa Polskiego, Galicji oraz zaboru pruskiego), a także dla tych niemieckich rejencji (lub ich części), które weszły w skład państwa polskiego po II wojnie światowej. Ogół wskazanych terytoriów łącznie tworzy więc obszar współczesnej Polski. Za takim podejściem przemawiaja istotne argumenty. Pozwala ono na porównywanie zjawisk i procesów gospodarczo-społecznych, dla których PKB jest ważną kategoria, w ujęciu longue durée. Funkcjonujące we współczesnej literaturze szacunki produkcji przemysłowej, danych ludnościowych czy PKB odnoszą się na ogół do współczesnych granic (przykładem są wspomniane dane Maddisona, ale także prace polskich historyków) ${ }^{22}$. Z drugiej strony liczne badania gospodarki ziem polskich w XIX w. uwzględniaja terytoria, które stanowią trzon tak dzisiejszego, jak przeszłego terytorium Polski (Królestwo Polskie, Galicja Zachodnia, obwód białostocki, Wielkopolska, część Śląska), a Ziemie Zachodnie i Północne, w tym Pomorze i Dolny Śląsk, traktują co najwyżej porównawczo. W naszym badaniu przyjmujemy metodę mieszana.

Jądrem naszej analizy jest PKB na poziomie regionalnym, uzupełnia go szacunek PKB dla całego terytorium współczesnej Polski, zestawiony w celu weryfikacji szacunków zagranicznych.

Jak z powyższego wynika, badaniom poddane zostały następujące obszary:

1) zabór rosyjski:

- Królestwo Polskie bez połowy guberni suwalskiej (pominięto powiaty, które weszły do współczesnej Litwy, uwzględniono powiat augustowski, prawie cały suwalski oraz mniejszą część sejneńskiego z Sejnami);

- gubernia grodzieńska - powiaty białostocki, bielski i sokólski;

2) zabór austriacki:

22 A. Maddison, dz. cyt.; zob. też The Maddison-Project. The 2013 Version, http:// www.ggdc.net/maddison/maddison-project/home.html (15 V 2016). Jeśli idzie o prace polskich historyków mamy na myśli m.in. monografie dotyczące gospodarki Ślasska czy Pomorza, niektóre w perspektywie sekularnej, od średniowiecza po czasy współczesne. 
- Galicja Zachodnia - cały obszar Izby Handlowej Kraków oraz siedem powiatów z Izby Handlowej Lwów: brzozowski, cieszanowski, jarosławski, krośnieński, leski, przemyski i sanocki i większość dobromilskiego;

- Śląsk Cieszyński - powiat bielski oraz część powiatów cieszyńskiego i frysztackiego;

3) zabór pruski:

- prowincja poznańska w całości (rejencje poznańska i bydgoska);

- prowincja Prusy Zachodnie w całości (rejencje kwidzyńska i gdańska);

4) Ziemie Zachodnie i Północne:

- z prowincji Pomorze - cała rejencja koszalińska oraz większość rejencji szczecińskiej (bez powiatów Demmin i Anklam, zdecydowanej większości powiatów Ückermünde i Randow oraz połowy powiatu Usedom-Wollin - większości wyspy Uznam);

- z prowincji Brandenburgia - powiaty z rejencji frankfurckiej: Torzym Zachód (Weststernberg), Torzym Wschód (Oststernberg), Krosno Odrzańskie (Crossen), Sulechów-Świebodzin (Züllichau-Schwiebus), Gorzów Wielkopolski (Landsberg), Myślibórz (Soldin), Choszczno (Arnswalde), Strzelce Krajeńskie (Friedeberg), prawie cały powiat Chojna (Königsberg), większość powiatu Żary (Sorau) oraz część wschodnia (około połowy) powiatu Gubin (Guben);

- z prowincji śląskiej - w całości rejencje opolska i wrocławska, większość rejencji legnickiej bez powiatów Wojrowice (Hoyerwerda), Rózbork (Rothenburg) i połowy powiatu Zgorzelec (Görlitz, bez większości miasta Zgorzelec) oraz niewielkiego fragmentu powiatu Żagań (Sagan);

- z prowincji Prusy Wschodnie - cała rejencja olsztyńska; powiaty z rejencji królewieckiej: Braniewo (Braunsberg), Lidzbark Warmiński (Heilsberg), Morag (Mohrungen), Pasłęk (Preußisch Holland), Kętrzyn (Rastenburg) i znaczne części powiatów Gierdawy (Gerdauen), Święte Siekierki (Heiligenbeil), Iława Pruska (Preußisch Eylau), Bartoszyce (Friedland); z rejencji gąbińskiej w całości powiaty Olecko (Oletzko) i Węgorzewo (Angerburg) oraz w części powiaty Gołdap (Goldap) i Darkiejmy (Darkehmen).

Ludność wskazanych jednostek, które w całości lub części znalazły się we współczesnych granicach Polski, przedstawia tabela 1. Ustalenie, w jakim zakresie poszczególne jednostki administracyjne weszły do terytorium dzisiejszej Polski stało się podstawą wag poszczególnych 
regionalnych produktów per capita w całkowitym produkcie gospodarki ziem dzisiejszej Polski.

Tabela 1. Ludność dziewiętnastowiecznych regionów, położonych w obecnych granicach Polski, na przełomie XIX i XX w.

\begin{tabular}{|c|c|c|c|c|}
\hline Państwo & Region & Populacja [1] & $\begin{array}{c}\text { Populacja } \\
\text { w obecnych } \\
\text { granicach } \\
\text { Polski [2] }\end{array}$ & $\begin{array}{c}{[2] /[1]} \\
\text { w procentach }\end{array}$ \\
\hline \multirow{11}{*}{ Rosja } & gubernia warszawska & 1931867 & 1931867 & 100,0 \\
\hline & gubernia piotrkowska & 1403901 & 1403901 & 100,0 \\
\hline & gubernia lubelska & 1160662 & 1160662 & 100,0 \\
\hline & gubernia płocka & 553633 & 553633 & 100,0 \\
\hline & gubernia siedlecka & 772146 & 772146 & 100,0 \\
\hline & gubernia łomżyńska & 579572 & 579572 & 100,0 \\
\hline & gubernia radomska & 814947 & 814947 & 100,0 \\
\hline & gubernia kielecka & 761995 & 761995 & 100,0 \\
\hline & gubernia kaliska & 840597 & 840597 & 100,0 \\
\hline & gubernia suwalska & 582912 & 176205 & 30,6 \\
\hline & gubernia grodzieńska & 1467173 & 477132 & 32,5 \\
\hline \multirow{3}{*}{ Austria } & Izba Handlowa Kraków & 2606739 & 2606739 & 100,0 \\
\hline & Izba Handlowa Lwów & 3730653 & 826217 & 22,2 \\
\hline & Śląsk Austriacki & 697740 & 113228 & 16,2 \\
\hline \multirow{13}{*}{ Niemcy } & rejencja poznańska & 1198252 & 1198252 & 100,0 \\
\hline & rejencja bydgoska & 689023 & 689023 & 100,0 \\
\hline & rejencja gdańska & 665992 & 665992 & 100,0 \\
\hline & rejencja kwidzyńska & 897666 & 897666 & 100,0 \\
\hline & rejencja opolska & 1868146 & 1868146 & 100,0 \\
\hline & rejencka wrocławska & 1697719 & 1697719 & 100,0 \\
\hline & rejencja legnicka & 1102992 & 868657 & 78,8 \\
\hline & rejencja frankfurcka & 1179250 & 652781 & 55,4 \\
\hline & rejencja szczecińska & 830709 & 614415 & 74,0 \\
\hline & rejencja koszalińska & 587783 & 587783 & 100,0 \\
\hline & rejencja olsztyńska ${ }^{a}$ & 519626 & 519626 & 100,0 \\
\hline & rejencja królewiecka & 876099 & 344556 & 39,3 \\
\hline & rejencja gąbińska & 600901 & 109704 & 18,3 \\
\hline
\end{tabular}

Legenda: a) Rejencja olsztyńska została utworzona w 1905 r. z czterech powiatów rejencji gąbińskiej i pięciu powiatów rejencji królewieckiej, liczba ludności powstała poprzez zsumowanie populacji powiatów, które weszły w jej skład, jednocześnie o odpowiednie kwoty zmniejszono populację rejencji gąbińskiej i królewieckiej.

Źródło: Spis rosyjski z 1897 r., spis austriacki z 1900 r. oraz spis niemiecki z 1900 r. 
Podstawowym źródłem informacji służącym oszacowaniu rozkładu PKB we wszystkich jednostkach administracyjnych, które znalazły się w dzisiejszych granicach Polski, jest wielkość ich zaludnienia. Została ona określona na podstawie danych spisowych z przełomu XIX i XX w. na poziomie powiatów. W przypadku powiatów, które jedynie częściowo znalazły się na obecnym terytorium Polski bądź które zmieniały przynależność do jednostek szczebla wyższego (guberni, rejencji), jako podstawę szacunku przyjęto stosowny odsetek ludności. Takie podejście niesie ze sobą ryzyko błędu, opiera się bowiem na założeniu o względnie równomiernym poziomie produktywności wewnątrz regionu w tym okresie. Ponieważ jednak operacja ta dotyczy najsłabiej rozwiniętych regionów pogranicza, można założyć, że nie wpływa ona istotnie na ostateczny wynik obliczeń ${ }^{23}$, zwłaszcza że tego typu metoda jest często stosowana w szacunkach historycznego $\mathrm{PKB}^{24}$, a analizy porównawcze wskazuja, że błąd oszacowania jest względnie niewielki.

\section{Metoda szacowania PKB}

W artykule szacujemy PKB dla dwóch lat: 1900 i $1910^{25}$. Ze względu na ograniczenia dotyczące jakości i rozdzielczości danych bazowych stosujemy dwie metody: produktową oraz bottom-up. Ta druga dotyczy Galicji (dla której posługujemy się obliczeniami wykonanymi przez Maxa-Stephana Schulzego). W przypadku guberni Królestwa Polskiego zastosowano obie metody, otrzymując nieco inne, choć zbliżone, wyniki do oszacowań Andreia Markevicha opierających się na centralnych statystykach rosyjskich ${ }^{26}$.

${ }^{23}$ Podejście to zakłada, że np. powiaty augustowski i suwalski guberni suwalskiej miały zbliżony poziom produktywności jak powiaty mariampolski, kalwaryjski, wołkowyszki czy władysławowski tejże guberni, które w skład państwa polskiego nie weszły. Większe wątpliwości można mieć w przypadku guberni grodzieńskiej, w Polsce znalazły się bowiem jej wyżej rozwinięte zachodnie powiaty. Podobna uwaga dotyczy rejencji królewieckiej. Jeśli idzie o powiaty wschodniej Galicji, do państwa polskiego weszły mniej rozwinięte powiaty obszaru Izby Handlowej Lwowskiej. Podsumowując, można założyć, że „niedobory” jednego obszaru są w jakimś stopniu wyrównywane przez „nadwyżki” pozostałych.

${ }^{24}$ P. Caruana-Galizia, Economic..., http://etheses.lse.ac.uk/3062/1/ (28 VII 2016).

${ }^{25} \mathrm{~W}$ związku $\mathrm{z}$ dokładnością dostępnych danych spisowych szacunki bazuja w przypadku terytorium niemieckiego na danych ze spisów gospodarczych z lat 1895 i 1907, dla zaboru rosyjskiego na danych ze spisu powszechnego z $1897 \mathrm{r}$. oraz rozproszonych danych dla Królestwa Polskiego z lat 1910-1912, dane dla części austriackiej, pochodzące z szacunków M.-S. Schulzego, zostały sporządzone na podstawie spisów z lat 1900 i 1910.

${ }^{26}$ Źródła danych zostaną szczegółowo omówione w kolejnym podrozdziale. 
Metoda produktowa zastosowana dla Królestwa Polskiego wychodzi z oszacowań wartości produkcji i usług w głównych sektorach gospodarki (rolnictwo, przemysł i usługi). W przypadku produkcji przemysłowej dokonaliśmy obliczeń produkcji netto według gałęzi i jednostek administracyjnych. Następnie wyniki odnoszące się do 1897 r. zdeflowaliśmy prostym indeksem cen do poziomu z $1910 \mathrm{r}$. Dane o produkcji rzemieślniczej sa przybliżone. W celu oszacowania jej poziomu w guberniach wykorzystaliśmy dane o populacji miejskiej, zakładając, że większość wartości dodanej rzemiosła była wytwarzana w miastach.

Wartość produkcji rolnej w Królestwie Polskim oszacowaliśmy według statystyk pogłowia, zbiorów i zużycia wewnętrznego w cenach z 1910 r., dodatkowo konfrontując je z obliczeniami produkcji w ujęciu wartościowym, przeprowadzonymi przez polskich historyków. Ze względu na zmiany przepisów podatkowych wielkość stada bydła i trzody chlewnej mogła zostać niedoszacowana w 1910 r. (ukrywanie pogłowia). W odniesieniu do produkcji sadowniczej i warzywniczej, która odgrywała znacząca rolę na początku XX w., dostępne są tylko przybliżenia jej wartości na poziomie całego Królestwa. Dla oszacowań na poziomie guberni przyjęliśmy, że dzieliła się ona proporcjonalnie do wielkości populacji wiejskiej. Z kolei produkcję leśną oszacowaliśmy, opierając się na danych dotyczacych pozyskania drewna oraz informacjach o zmianie powierzchni zalesienia. Ponieważ obejmują one teren Królestwa, można przyjąć upraszczające założenie, że dochody z produkcji leśnej są proporcjonalne do powierzchni, co niesie ryzyko nieznacznego przeszacowania wartości dochodów w sektorze dla guberni gęsto zaludnionych i niedoszacowania w pozostałych. Produkcja leśna odgrywała jednak marginalna rolę w gospodarce Królestwa Polskiego, pomimo znacznej skali wycinki lasów.

Wartość sektora usług oszacowaliśmy następująco: w odniesieniu do usług osobistych (służba domowa itp.) przyjęliśmy, że wartość dodana jest równa wynagrodzeniu ${ }^{27}$, w odniesieniu do usług rynkowych wykorzystaliśmy - na ile to było możliwe - dane podatkowe, w pozostałych przypadkach opieraliśmy się na informacjach o wynagrodzeniach. Wartość usług publicznych oszacowaliśmy na podstawie statystyk budżetu państwa. Konieczne było skorygowanie spisowych statystyk zatrudnienia w sektorze usług (opis metody przedstawiamy w następnym podrozdziale). Szacunki dochodów z kapitału, zysków banków, kolei i poczty opierają się na danych tychże instytucji oraz statystykach podatkowych. $\mathrm{Z}$ kolei w szacunkach wartości wytworzonej w sektorze budowlanym

${ }_{27}$ Por. A. Markevich, dz. cyt. 
bazujemy na cenach nieruchomości i dochodów z nich pochodzących (informacje ubezpieczeniowe i podatkowe). Względnie wiarygodne sa dane dotyczące wartości nieruchomości miejskich, natomiast wartość nieruchomości wiejskich i przemysłowych oszacowaliśmy z uwzględnieniem odpowiednio populacji wiejskiej oraz wartości produkcji przemysłowej w guberniach. Wydatki na rozwój infrastruktury drogowej i kolejowej sa przybliżeniem opartym na danych o dynamice rozbudowy sieci drogowej i kolejowej. Koszty utrzymania infrastruktury przyjęliśmy na poziomie porównywalnym do austriackiego.

Uzyskane wyniki dotyczące wartości produkcji w poszczególnych sektorach wykorzystaliśmy do oszacowania wartości dodanej. Przy określaniu jej poziomu w poszczególnych branżach przemysłu posłużyliśmy się ustaleniami Andreia Markevicha dla Rosji, z kolei w odniesieniu do rzemiosła i przemysłu wydobywczego - ustaleniami László Katusa dla Węgier. Wartość dodaną w rolnictwie, tam gdzie to było możliwe, wyznaczyliśmy na podstawie danych podanych przez Juliusza Łukasiewicza, w pozostałych przypadkach za Maxem-Stephanem Schulzem. Założenia tego ostatniego zastosowaliśmy także w odniesieniu do wartości dodanej budownictwa.

Odrębnych oszacowań wymagała gubernia grodzieńska, a raczej jej zachodnia część. Ze względu na brak spójnych danych przyjęliśmy PKB per capita na poziomie średniej arytmetycznej graniczacych z nia guberni Królestwa Polskiego. Zasadność tego uproszczonego oszacowania potwierdzają dane o strukturze zatrudnienia w 1897 r., wyniki Markevicha dotyczace tej guberni dla $1897 \mathrm{r}$. oraz dane o poziomie urbanizacji ${ }^{28}$.

$\mathrm{W}$ odniesieniu do ziem polskich zaboru pruskiego i ziem niemieckich zastosowanie metody bottom-up dla poziomu rejencji nie było możliwe. W związku z tym wykorzystaliśmy oszacowanie regionalnego PKB dla Niemiec w 1907 r., dokonane przez Haralda Franka ${ }^{29}$ na bazie danych podatkowych. Następnie w celu oszacowania PKB dla roku spisu gospodarczego 1895 wykorzystaliśmy metodologię Paula Caruany-Galizii ${ }^{30}$, która jednak, w odróżnieniu od tego autora, zastosowaliśmy do skorygowanych i oczyszczonych danych o strukturze zatrudnienia i populacji.

${ }_{28}$ P. Koryś, M. Tymiński, Occupational Structure in the Polish Territories at the Turn of the 20th (1895-1900) Century, ,Working Papers from Faculty of Economic Sciences, University of Warsaw" 2015, nr 9; A. Markevich, dz. cyt.; A. Jelonek, Ludność miast $i$ osiedli typu miejskiego na ziemiach Polski od 1810 do 1960 r., Warszawa 1968 („Dokumentacja Geograficzna”, 3-4).

${ }^{29}$ H. Frank, Regionale Entwicklungsdisparitäten im deutschen Industrialisierungsprozess 1849-1939. Eine empirisch-analytische Untersuchung, Hamburg 1995.

${ }^{30}$ P. Caruana-Galizia, Economic... 
Metoda ta opiera się na założeniu, że podstawowy wpływ na zmiany produktywności w poszczególnych regionach Europy drugiej połowy XIX w. miała realokacja zasobów pracy z rolnictwa do przemysłu i (w mniejszym stopniu) do usług. Dzięki temu, że dla Niemiec dla lat 1871, 1882, 1895 i 1907 dostępne sa szczegółowe dane spisowe (na poziomie rejencji i powiatów, według zajęć ludności), możliwe było ustalenie trójsektorowej struktury zatrudnienia na poziomie regionalnym ${ }^{31}$. Następnie na danych z $1907 \mathrm{r}$. oszacowaliśmy model wiążący poziom PKB w każdej z 69 rejencji (GDP) z liczebnościa jej populacji (POP) i udziałem pracujących w przemyśle (I) oraz usługach (S), tj.

$$
\ln G D P_{i, 1907}=\alpha+\beta \ln P O P_{i, 1907}+\gamma \ln I_{i, 1907}+\delta \ln S_{i, 1907}+\epsilon_{i}
$$

Tym samym, zakładając stabilność wyestymowanych elastyczności $\alpha, \gamma$ i $\delta \mathrm{w}$ czasie oraz posługując się danymi regionalnymi Franka dla 1907 r., można oszacować zmianę PKB w każdej z rejencji między 1895 a 1907 r., tj.

$$
\begin{gathered}
\ln G D P_{i, 1895}=\ln G D P_{i, 1907}-\beta\left(\ln P O P_{i, 1907}-\ln P O P_{i, 1895}\right)- \\
-\gamma\left(\ln I_{i, 1907}-\ln I_{i, 1895}\right)-\delta\left(\ln S_{i, 1907}-\ln S_{i, 1895}\right)+\epsilon_{i}
\end{gathered}
$$

a także, w sposób analogiczny dla lat 1882 i 1871. Innymi słowy, zakładamy, że stopa wzrostu regionalnego PKB per capita jest proporcjonalna (z uwzględnieniem elastyczności $\beta, \gamma$ i $\delta$ ) do zmiany odsetka zatrudnionych $\mathrm{w}$ przemyśle i usługach, co należy wiązać $\mathrm{z}$ dominującym znaczeniem, jakie dla wzrostu gospodarczego w XIX w. miała realokacja nadwyżkowych zasobów pracy poza rolnictwo. Świadczy o tym m.in. to, że oszacowana przez nas relacja okazuje się być w latach 1870-1910 bardzo bliska tej, jaka można wyznaczyć dla wyższego poziomu agregacji, tj. pomiędzy krajami europejskimi, dla których dostępne sa dane o poziomie PKB, populacji i strukturze zatrudnienia $\mathrm{w}$ tym czasie.

Zastosowanie tej samej metody dla Austrii i Szwecji, dla których istnieją niezależne oszacowania $\mathrm{PKB}^{32}$, prowadzi do różnicy rzędu 5-6\% dla 10-15-letnich okien czasowych. Dokładniejsze przetworzenie danych spisowych dodatkowo ten błąd zmniejsza: suma regionalnych PKB, tj. uzyskany przez nas wynikowy PKB zagregowany dla całych Niemiec, okazał się być we wszystkich okresach bardzo bliski szeregowi oszacowanemu

${ }^{31}$ P. Koryś, M. Tymiński, dz. cyt.; ciż, Struktura zawodowa ziem polskich na przetomie XIX $i$ XX w., RDSG, t. 75, 2015, s. 129-166.

${ }^{32}$ M.-S. Schulze, Regional...; K. Enflo, M. Henning, L. Schön, Swedish Regional GDP 1855-2000. Estimations and General Trends in the Swedish Regional System, „Research in Economic History” 30, 2014, s. 47-89. 
przez Walthera G. Hoffmanna ${ }^{33}$ - różnica nie przekroczyła 3\%. Wskazuje to, że założenie o stabilności elastyczności $\beta, \gamma$ i $\delta$ nie tylko dla lat 1895 -1907, ale i dla całego okresu 1871-1907 nie powinno prowadzić do znaczących błędów prognozy. Warto podkreślić, że wyniki w krótkich oknach czasowych (np. pomiędzy 1895 a 1907) są zapewne mało obciążone.

Dla zapewnienia porównywalności danych z szacunkami międzynarodowymi wszystkie wartości sa podane w dolarach międzynarodowych (Geary'ego-Khamisa, dalej: GK) w parytecie dla 1990 r. Parytety rubla, korony austriackiej i marki niemieckiej zostały ustalone na podstawie ustaleń autorów oszacowań PKB Rosji, Austrii i Niemiec wykorzystanych w bazie danych Maddison-Project ${ }^{34}$.

\section{Źródła danych}

Oszacowania PKB we wskazanym wyżej ujęciu wymagały w pierwszej kolejności sięgnięcia do opracowań zawierających zestawione w możliwie długich szeregach czasowych statystyki kategorii pośrednich (produkcja rolna, przemysłowa, usługi, transport oraz produkcja pozostałych działów gospodarki, struktura zatrudnienia). Historiografia gospodarcza dotycząca lat 1870-1914 jest ogromna, liczy zapewne kilkaset monografii i artykułów, problem polega na tym, że te z nich, które zawieraja zestawienia pozwalające na analizy kwantytatywne, dotyczą bądź jednej z dzielnic zaborczych, bądź wybranych dziedzin (sektorów) gospodarki, często z dużymi lukami. Wynikało to m.in. z braku zagregowanych oficjalnych danych, to zaś spowodowane było późnym zorganizowaniem publicznych służb statystycznych, przy czym najsłabsze były i najpóźniej powstały rosyjskie instytucje statystyczne.

Odnośnie do zaboru rosyjskiego dopiero na początku XX w. zaczęły pojawiać się autorskie roczniki statystyczne oraz opracowania zawierające mniej lub bardziej rozbudowane zestawienia produkcji dóbr i usług, struktury zawodowej ludności czy stopnia urbanizacji, które dziś pozwalają przybliżyć strukturę tamtej gospodarki ${ }^{35}$. Relatywnie najpełniejsze

${ }_{33}$ W.G. Hoffmann, Das Wachstum der Deutschen Wirtschaft Seit der Mitte des 19. Jahrhunderts, Berlin 1965.

${ }^{34}$ Por. The Maddison-Project...

35 Najważniejsze dane zestawiają roczniki: E. Strasburger, Rocznik Statystyczny Królestwa Polskiego z uwzględnieniem innych ziem polskich. Rok 1915, Warszawa 1916; W. Grabski, Rocznik Statystyczny Królestwa Polskiego. Rok 1913, Warszawa 1914; tenże, Rocznik Statystyczny Królestwa Polskiego. Rok 1914, Warszawa 1915; A. Krzyżanowski, K. Kumaniecki, Statystyka Polski, Kraków 1915; E. Romer, 
są statystyki produkcji przemysłowej obejmujacce zestawienia ilościowe (rzadziej wartościowe), produktowe oraz zatrudnieniowe. Niestety obejmują one zazwyczaj duży i średni przemysł, często dane dla tych samych lat podawane przez różnych autorów są sprzeczne ${ }^{36}$. Liczne są monografie okręgów przemysłowych, niestety są one przydatne w ograniczonym stopniu z uwagi na fragmentaryczność danych, pozwalaja natomiast na uzupełnienie zestawień pochodzących z innych źródeł ${ }^{37}$. Podobna uwaga dotyczy opracowań poświęconych najważniejszym przemysłom ${ }^{38}$. Nie posiadamy natomiast prawie żadnych wiarygodnych statystyk dotyczących drobnego przemysłu, rzemiosła czy tzw. przemysłu wiejskiego. Dysponujemy dla tych działów jedynie szczątkowymi, jednostkowymi informacjami ${ }^{39}$. Gros użytecznych danych zawierają natomiast źródła podstawowe, w postaci prac Warszawskiego Komitetu Statystycznego oraz statystyki rosyjskie ${ }^{40}$.

I. Weinfeld, Rocznik Polski. Tablice statystyczne, Kraków 1917. Użyteczne sa monografie: W. Załęski, Królestwo Polskie Królestwo Polskie pod względem statystycznym, cz. 1-2, Warszawa 1900-1901; tenże, Statystyka porównawcza Królestwa Polskiego, Warszawa 1876; S. Koszutski, Rozwój ekonomiczny Królestwa Polskiego w ostatniem trzydziestoleciu (1870-1900), Warszawa 1905.

36 J. Łukasiewicz, Przewrót techniczny w przemyśle Królestwa Polskiego 1852-1886, Warszawa 1963; tenże, Dynamika rozwoju przemystu na ziemiach polskich. Indeks produkcji przemystowej w latach 1870-1913, w: Gospodarka przemysłowa i poczatki cywilizacji technicznej $w$ rolniczych krajach Europy. Studia i materiaty, red. I. Pietrzak-Pawłowska, Wrocław 1977, s. 101-112; tenże, Poczqtki cywilizacji przemysłowej na ziemiach polskich, Warszawa 1988; W. Puś, Przemyst Królestwa Polskiego w latach 1870-1914. Problemy struktury i koncentracji, Łódź 1984; tenże, Statystyka przemystu Królestwa Polskiego w latach 1879-1913. Materiały źródłowe, Łódź 2013.

${ }^{37}$ I. Ihnatowicz, Przemyst tódzki w latach 1860-1900, Wrocław-Warszawa-Kraków 1965; W. Pruss, Rozwój przemystu warszawskiego w latach 1864-1914, Warszawa 1977; W. Puś, Dzieje Łodzi przemysłowej. Zarys historii, Łódź 1987.

38 J. Godlewski, Przemyst cukrowniczy w Królestwie Polskim 1870-1914, Białystok 2009; Rozwój przemystu rolno-spożywczego na ziemiach polskich w XIX $i$ XX w., red. C. Łuczak, Poznań 1970; Dzieje cukrownictwa w Polsce, red. C. Łuczak, Poznań 1981; A. Jezierski, E. Kaczyńska, S. Kowalska, K. Piesowicz, Ekonomika górnictwa i hutnictwa $w$ Królestwie Polskim 1840-1910, Warszawa 1961; Zarys dziejów górnictwa na ziemiach polskich, t. 2, red. J. Pazdur, Katowice 1961.

39 Dane na ich temat przywołuje S. Koszutski, dz. cyt. Interesujące dane podaje A. Zakrzewski, Przemyst włościański. Teoria kwestyi, jej stan i widoki u nas. Szkic ekonomiczny, Warszawa 1888, niestety praca, ze względu na datę powstania, nie obejmuje interesującego nas okresu. Szczątkowe informacje o stanie przemysłu drobnego zawiera opracowanie Warszawskiego Komitetu Statystycznego: Fabriczno-zawodskajakustarnaja i domasznaja promyszlennost $w$ dziesiati guberniach Carstwa Polskago k naczału 1901 goda, ,Trudy Warszawskogo Statisticzeskogo Komitieta” 1907, z. 29.

${ }^{40}$ Zob. m.in.: K. Vobłyj, Razwitiefabriczno-zawodskoj promyszlennosti w 10 guberniach Carstwa Polskago c 1876 po 1906 god, „Trudy Warszawskogo Statisticzeskogo Komitieta" 1907, z. 29; Fabriczno-zawodskajapromyszlenniost w Privislanskim Kraje 
Zdecydowanie uboższe od przemysłowych są statystyki podstawowego działu gospodarki, jakim było rolnictwo. Dysponujemy kilkoma opracowaniami zawierającymi oszacowania produkcji roślinnej oraz hodowli ${ }^{41}$, podstawową trudność sprawia natomiast obliczenie konsumpcji własnej, zużycia pośredniego oraz produkcji netto. $\mathrm{W}$ tym zakresie pomocne sa dane rosyjskie określające produkcję netto zbóż czy metody szacowania dochodu społecznego wytwarzanego przez rolnictwo zastosowane przez Bohdana Dederkę dla lat 20. XX w. ${ }^{42}$ Staraliśmy się uwzględnić również produkcję sadowniczą i warzywniczą.

Jeśli idzie o pozostałe działy gospodarki stan badań ilościowych jest jeszcze bardziej ograniczony. W przypadku transportu kolejowego monografie linii kolejowych podaja jedynie liczby dotyczace przewozów (i to niepełne $)^{43}$. Lepszy obraz mamy dla lat 1908-1913, dysponujemy bowiem danymi dotyczacymi przychodów, kosztów i dochodów netto linii kolejowych $^{44}$. Nie posiadamy informacji ilościowych dotyczących handlu oraz sektora usług, w tym publicznych. Dysponujemy za to jednostkowymi informacjami o poziomie zarobków i płac w poszczególnych zawodach.

Strukturę zawodową ludności w zaborze rosyjskim możemy odtworzyć na podstawie spisu powszechnego z $1897 \mathrm{r} .{ }^{45}$ Dla pozostałych lat

za 1906 god k naczatu 1907, „Trudy Warszawskogo Statisticzeskogo Komitieta” 1907, z. 22; Dziesiat guberni carstwa Polskago w cifrach, „Trudy Warszawskogo Statisticzeskogo Komitieta" 1908, z. 35; Svod danych fabriczno-zawodskoj promyszlennosti $w$ Rossii. Materiaty Torgowo-Promyszlennoj Statistiki (lata 1885-1887, 1888, 1891, 1893), S. Petersburg 1889-1896; Svodotczetow fabrycznych inspektorow (lata 1902-1912), S. Petersburg 1904-1912.

41 J. Łukasiewicz, Drogi rozwoju rolnictwa na ziemiach polskich, w: Polska XIX wieku: państwo, społeczeństwo, kultura, red. S. Kieniewicz, Warszawa 1986; tenże, Kryzys agrarny na ziemiach polskich w końcu XIX wieku, Warszawa 1968; T. Sobczak, Przełom w konsumpcji spożywczej $w$ Królestwie Polskim $w$ XIX wieku, Wrocław 1968; Stosunki rolnicze Królestwa Kongresowego, Warszawa 1918; Zarys historii gospodarstwa wiejskiego $w$ Polsce, t. 2-3, red. J. Leskiewiczowa, Warszawa 1964-1970.

${ }^{42}$ Sielskoje choziajstwo, w: Dinamika ekonomiczeskowo $i$ socjalno worazwitia Rossii w XIX wieke - $k$ naczalie XX wieka, http://www.hist.msu.ru/Dynamics/06_agr.html (14 V 2016); B. Dederko, dz. cyt.

${ }^{43}$ H. Hilchen, Historia drogi żelaznej Warszawsko-Wiedeńskiej (1835-1848-1898). Historia drogi żelaznej Warszawsko-Wiedeńskiej, Warszawa-Kraków 1912; J. Gieysztor, Koleje żelazne na ziemiach polskich, Warszawa 1918; Studia z dziejów kolei żelaznych w Królestwie Polskim: 1840-1914, red. R. Kołodziejczyk, Warszawa-Łódź 1970.

${ }^{44}$ Otczet Warszawskawo Porajonawo Komiteta po regulirowaniju masowych pieriewozow gruzow po zielieznym dorogam za 1911 god, Warszawa 1912; Otczet Warszawskawo Porajonawo Komiteta po regulirowaniju masowych pieriewozow gruzow po żielieznym dorogam za 1913 god, Warszawa 1914.

${ }^{45} \mathrm{O}$ wartości danych spisowych zob. S. Szulc, Wartość materiatów statystycznych dotyczqcych stanu ludności b. Królestwa Polskiego, Warszawa 1920. 
konieczne było dokonywanie szacunków na podstawie danych pośrednich dotyczacych ludności i urbanizacji. Podkreślić tu trzeba, że statystyki populacji $\mathrm{w}$ odniesieniu do zaboru rosyjskiego nie sa $\mathrm{w}$ pełni wiarygodne. O ile względnie poprawny wydaje się spis z 1897 r., o tyle dane dla lat późniejszych pochodzące z oszacowań rosyjskiej administracji uważa się, przynajmniej dla końca tego okresu, za przeszacowane ${ }^{46}$. Może to wyjaśniać zaskakująco niską dynamikę rozwoju niektórych guberni (np. piotrkowskiej).

W obliczeniach zostały też uwzględnione statystyki podatkowe i budżetowe ${ }^{47}$, które pozwoliły na oszacowanie wartości usług publicznych oraz dochodów z nieruchomości (od początku XX w. w opodatkowaniu uwzględniano wartość dochodów z nieruchomości w miastach). Z kolei statystyki ubezpieczeniowe pozwoliły na przybliżenie wartości majątku trwałego. Informacje na temat kosztów armii rosyjskiej na ziemiach polskich sa ograniczone (najdokładniejsze dla 1897 r.), niemniej dostępne są cząstkowe dane na temat budżetu wojska.

W przypadku terenów znajdujących się w granicach Niemiec ze względu na metodę przyjęta do szacowania regionalnych produktów brutto per capita wykorzystujemy dane o strukturze zatrudnienia na poziomie rejencji. Informacje pochodzą z niemieckich spisów gospodarczych z 1895 i 1907 r. ${ }^{48}$ Zawierają one dane dla kilkudziesięciu kategorii zawodowych podzielonych na sześć działów: 1) rolnictwo, hodowla, leśnictwo i rybołówstwo (A), 2) górnictwo i przemysł (wliczając w to rzemiosło) (B), 3) handel i transport, usługi finansowe (C), 4) służba (D), 5) służba publiczna i wolne zawody (E), 6) bez zatrudnienia (F). W każdej profesji rozróżnianych było kilka kategorii pracowników i osób utrzymujących się z ich dochodów. Dla naszych celów wykorzystaliśmy jedynie dane dotyczące osób czynnych zawodowo, co wykluczyło całą kategorię F. Poza tym wyodrębniliśmy osoby zatrudnione jako służba w gospodarstwach domowych. Były one przypisane do profesji wykonywanej przez głowę rodziny, np. w systemie spisowym służąca w domu kowala była przypisana do kategorii B, należąc do podkategorii służba domowa utrzymywana przez głowę rodziny. Osoby te zostały przez nas zakwalifikowane do ogólnej kategorii służących (D).

Wprowadziliśmy również istotną korektę w odniesieniu do liczby kobiet „pracujących” w rolnictwie w 1895 r. (problem dotyczy podziału

${ }^{46}$ Tamże.

${ }^{47}$ A. Krzyżanowski, K. Kumaniecki, dz. cyt.

${ }^{48}$ Berufsstatistik der Bundesstaaten nach der Zählung vom 14. Juni 1895, „Statistik des Deutschen Reichs”, Neue Folge, 104, 1897; Berufsstatistik nach der Zählung vom 12. Juni 1907, „Statistik des Deutschen Reichs”, Neue Folge, 204, 1909. 
kobiet na pracujące i utrzymywane przez głowę rodziny). Dane spisowe wskazywały, iż ich liczba była wyraźnie niższa w porównaniu z 1907 r. Wskazówką do przeprowadzenia tej korekty były ustalenia Walthera Hoffmanna. Zasygnalizował on niedoszacowanie liczby kobiet pracujacych w rolnictwie w spisach z 1882 i 1895 r. w porównaniu do spisu z 1907 r. Według jego obliczeń różnica była bardzo znacząca (dotyczyła około 1,5 mln kobiet w skali całych Niemiec) i najprawdopodobniej wynikła z odmiennego kwalifikowania kobiet „pracujących” w spisach z 1882 i 1895 r. ${ }^{49}$ Ponieważ nie ma żadnej dokumentacji uzasadniajacej ów gwałtowny wzrost partycypacji kobiet w rolniczej sile roboczej przyjęliśmy, że struktura aktywności kobiet w rolnictwie w $1895 \mathrm{r}$. w poszczególnych rejencjach była taka sama jak w 1907 r. Oznaczało to wzrost odsetka kobiet „pracujących” w badanych rejencjach do około $40 \%$ wszystkich kobiet w gospodarstwach rolnych. Wydaje się to wiarygodnym poziomem, podobne wartości przyją m.in. Max-Stephan Schulze dla rolnictwa w Austrii ${ }^{50}$.

Przy ostatecznej agregacji danych posłużyliśmy się metodą PST (Primary - Secondary - Tertiary), która jest często stosowana w analizach historycznej struktury zawodowej ${ }^{51}$. W oryginalnym podejściu do działu pierwszego zalicza się wszystkie gałęzie przypisywane do kategorii rolnictwo oraz - co może nieco zaskakiwać - górnictwo. Edward Anthony Wrigley tłumaczy to tym, że w dziale pierwszym powinny się znaleźć wszystkie dziedziny, które sa związane z dostarczaniem na rynek szeroko rozumianych surowców ${ }^{52}$. Jednak badacze analizujacy strukturę zawodową nie są w tym przypadku konsekwentni i część z nich, jak np. Leigh Shaw-Taylor ${ }^{53}$, podąża za tradycja urzędów statystycznych, zaliczając górnictwo do działu drugiego, co tłumaczy się zmiana jego charakteru w trakcie rewolucji przemysłowej. Z tego powodu, podobnie jak Shaw-Taylor, zaliczamy górnictwo do działu drugiego. W efekcie w dziale pierwszym (Primary) znalazła się cała kategoria A ze spisów

${ }^{49}$ W.G. Hoffmann, dz. cyt., s. 183 (tłum. autorów).

${ }^{50}$ M.-S. Schulze, Origins of Catch-up Failure. Comparative Productivity Growth in the Habsburg Empire, 1870-1910, „European Review of Economic History” 2007, nr 11, s. 212 n.

51 E.A. Wrigley, The PST System of Classifying Occupations, http://www.geog.cam. ac.uk/research/projects/occupations/britain19c/papers/paper1.pdf (1 III 2016). Ten sam system przyjął w obliczeniach regionalnego PKB Niemiec Paul Caruana-Galizia.

52 Tamże.

${ }^{53}$ L. Shaw-Taylor, The Occupational Structure of England and Wales, c. 1750 -1911, Paper prepared for the INCHOS workshop held in Cambridge, 29-31 VII 2009, http://www.geog.cam.ac.uk/research/projects/occupations/britain19c/papers/paper5. pdf (1 VIII 2016). 
1895 i 1907 r. W dziale drugim (Secondary) poza górnictwem mieszcza się wszystkie zawody umiejscawiane w kategorii przemysł i rzemiosło, a zatem do działu drugiego wchodzi cała kategoria B ze spisów 1895 i 1907 r. Na dział trzeci (Tertiary) składają się wszelkiego rodzaju usługi: transport i handel, finanse, służba oraz administracja publiczna, armia i wolne zawody (kategorie spisowe C, D i E oraz służba domowa przypisana do głowy rodziny ze wszystkich kategorii spisowych).

W odniesieniu do zaboru austriackiego wykorzystaliśmy oszacowania Schulzego ${ }^{54}$, który w obliczeniach regionalnego PKB dla ziem austriackich zastosował metodę bottom-up.

\section{Wyniki}

Szacunki poziomu PKB dla analizowanych obszarów przedstawiają wykresy 1 i 2 . Najwyższy PKB osiagały jednostki administracyjne o największej liczbie ludności i najsilniej uprzemysłowione: gubernie warszawska i piotrkowska w Królestwie Polskim oraz rejencje opolska i wrocławska leżace w granicach Niemiec, przy czym najszybsze tempo wzrostu miały gubernia warszawska oraz rejencja opolska, odpowiednio 4,73 oraz 3,67\% średnio rocznie. Odnotować też należy wysoki poziom produktu Galicji Zachodniej, wynikał on przede wszystkim z dużej liczby ludności tej prowincji.

Spośród czterech głównych dzielnic składających się na terytorium dzisiejszej Polski największy wzrost PKB odnotował zabór rosyjski (o około 75\%). Mniej więcej o 40\% wzrósł produkt rejencji niemieckich na Ziemiach Zachodnich i Północnych. Nieco słabszy wzrost odnotowały ziemie zaboru austriackiego, wyniósł on nieco ponad $36 \%$, a najmniejszy odnotowały dwie prowincje składające się na zabór pruski (poznańska i zachodniopruska), wyniósł on około 26\%. Wartość PKB dla całego analizowanego terytorium na przełomie XIX i XX w. wyniosła 36723 mln dolarów (GK USD'1990), a około dziesięć lat później wzrosła do 54794 mln GK USD'1990, czyli o niecałe 39\%.

Przedstawione powyżej szacunki PKB pokazują wzrost globalnej wartości produkcji w poszczególnych regionach oraz na całym analizowanym terytorium, jednak jej poziom jest w znacznej mierze uwarunkowany wielkością i szybkością wzrostu populacji. Wpływ czynnika demograficznego nie pozwala na jednoznaczne określenie, które obszary dzisiejszego terytorium Polski były lepiej rozwinięte gospodarczo oraz w których

\footnotetext{
${ }^{54}$ M.-S. Schulze, Regional...
} 
Wykres 1. PKB obszarów tworzących obecne terytorium Polski na przełomie XIX i XX w. oraz około 1910 r. (w tys. GK USD’1990)

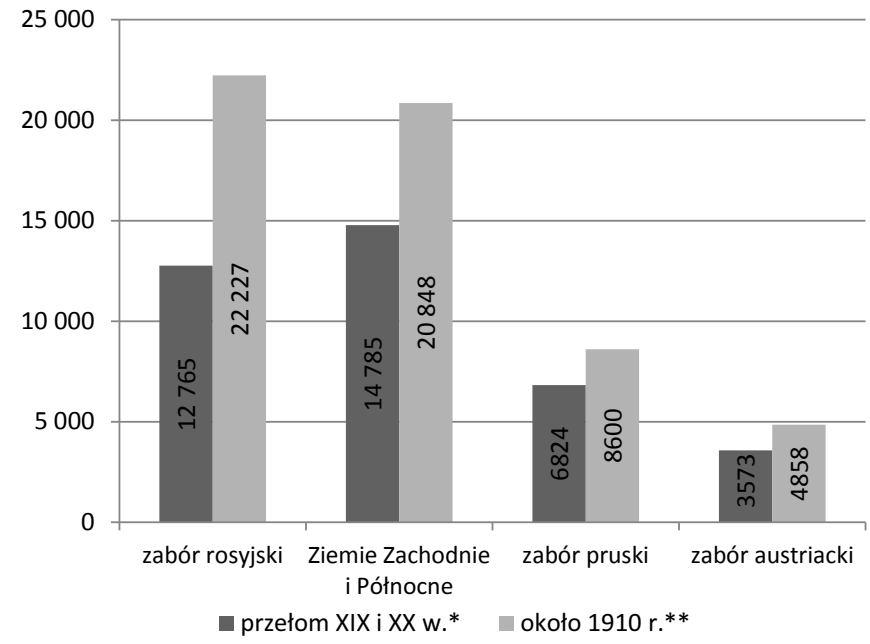

Legenda: * zabór rosyjski - 1897, zabór austriacki - 1900, ziemie na terenie Niemiec - 1895; ** zabór rosyjski - 1912, zabór austriacki - 1910, ziemie na terenie Niemiec - 1907.

Źródło: oprac. własne na podstawie szacunków regionalnego PKB; dane dla obszarów leżących we współczesnych granicach Polski zgodnie z opisem w podrozdz. „Zakres geograficzny badania”.

Wykres 2. PKB według jednostek administracyjnych (guberni, rejencji) leżących we współczesnych granicach Polski na przełomie XIX i XX w. oraz około 1910 r. (w tys. GK USD'1990)

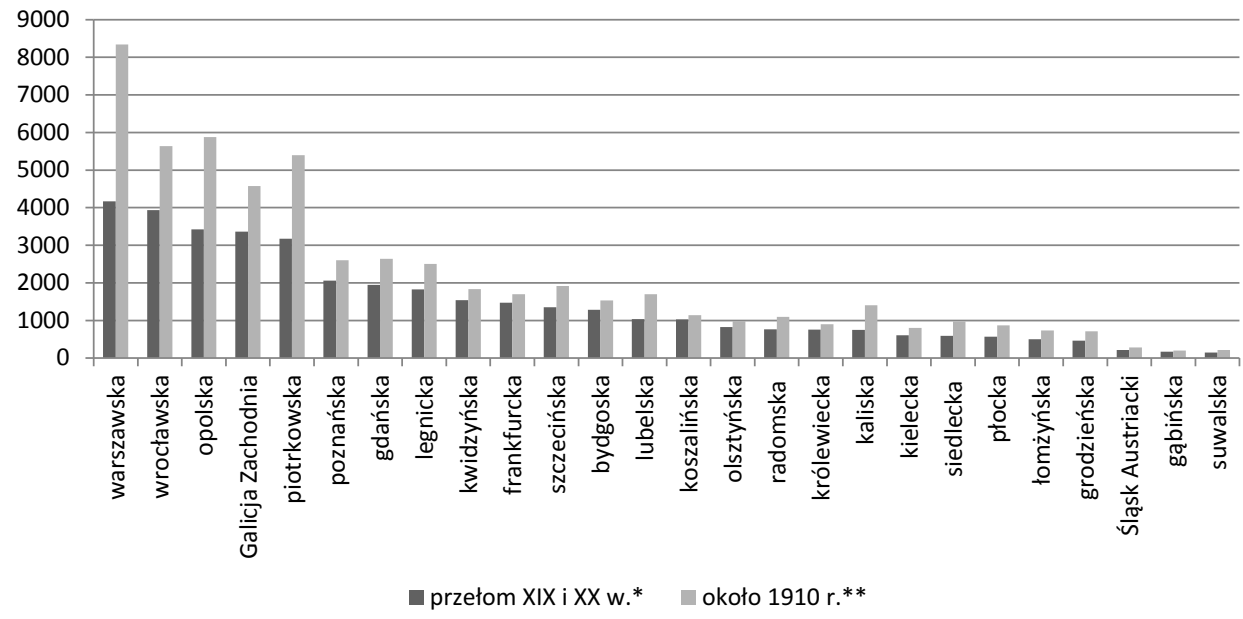

Legenda: * zabór rosyjski - 1897, zabór austriacki - 1900, ziemie na terenie Niemiec - 1895; ** zabór rosyjski - 1912, zabór austriacki - 1910, ziemie na terenie Niemiec - 1907.

Źródło: oprac. własne na podstawie szacunków regionalnego PKB; dane dla obszarów leżących we współczesnych granicach Polski zgodnie z opisem w podrozdz. „Zakres geograficzny badania”. 
Wykres 3. PKB per capita obszarów tworzacych obecne terytorium Polski na przełomie XIX i XX w. oraz około 1910 r. (w tys. GK USD’1990)

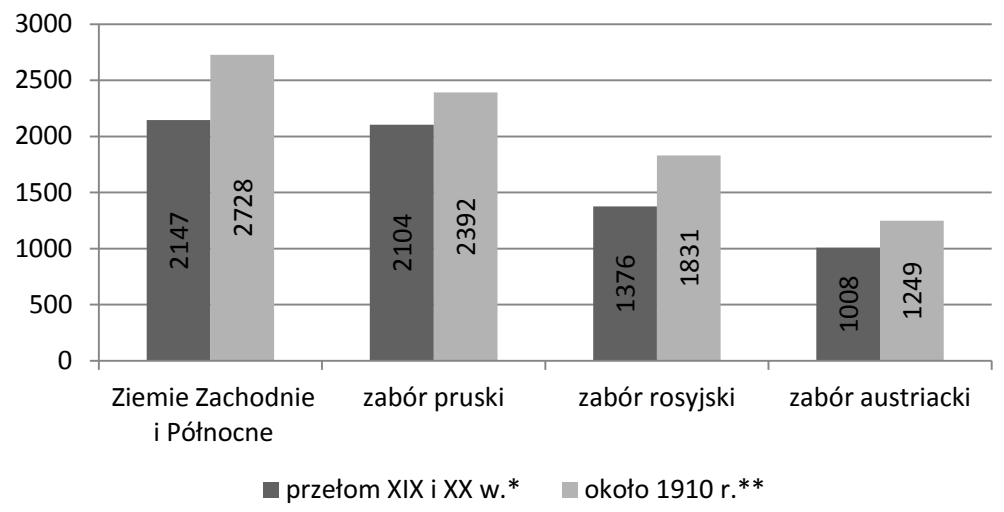

Legenda: * zabór rosyjski - 1897, zabór austriacki - 1900, ziemie na terenie Niemiec - 1895; ** zabór rosyjski - 1912, zabór austriacki - 1910, ziemie na terenie Niemiec - 1907.

Źródło: oprac. własne na podstawie szacunków regionalnego PKB; dane dla obszarów leżących we współczesnych granicach Polski zgodnie z opisem w podrozdz. „Zakres geograficzny badania”.

z nich wzrost gospodarczy miał większą dynamikę. Rozstrzygnięcie tej kwestii umożliwia zestawienie wielkości PKB per capita i jego wzrost $\mathrm{w}$ analizowanych dzielnicach ${ }^{55}$ (zob. wykresy $3,4,5$ i 6 ).

Poziom PKB per capita na terenach należących przed II wojną światową do Niemiec był zdecydowanie najwyższy wśród czterech opisanych wyżej głównych obszarów terytorium dzisiejszej Polski (zob. wykres 3). Na Ziemiach Zachodnich i Północnych włączonych do Polski po II wojnie światowej PKB per capita wynosił pod koniec XIX w. 2135 GK USD'1990, a pod koniec pierwszej dekady XX w. 2704 GK USD'1990, z kolei na ziemiach zaboru pruskiego wielkości te wynosiły odpowiednio 2104 i 2392 GK USD'1990. Zdecydowanie niższy poziom można zaobserwować na ziemiach zaboru rosyjskiego, odpowiednio 1380 i 1842 GK USD'1990. Najniższe wskaźniki notuje zabór austriacki, w którym w 1900 r. PKB per capita wynosił 1010 GK USD'1990, a w 1910 r. 1251 GK USD'1990.

Szacunki PKB per capita na poziomie regionów pozwalają wyróżnić trzy wyraźnie odmienne grupy. Pierwsza, która już pod koniec XIX w. charakteryzuje się poziomem PKB per capita powyżej 2 tys. GK USD'1990 składa się z dwóch najlepiej rozwiniętych guberni Królestwa Polskiego (warszawskiej i piotrkowskiej), jednej rejencji

${ }_{55}$ Wyjątkiem jest tu wschodnia część rejencji opolskiej, która znalazła się w granicach Polski już po I wojnie światowej. 
Wykres 4. PKB per capita według jednostek administracyjnych (guberni, rejencji) leżacych we współczesnych granicach Polski, na przełomie XIX i XX w. oraz około 1910 r. (w tys. GK USD'1990)

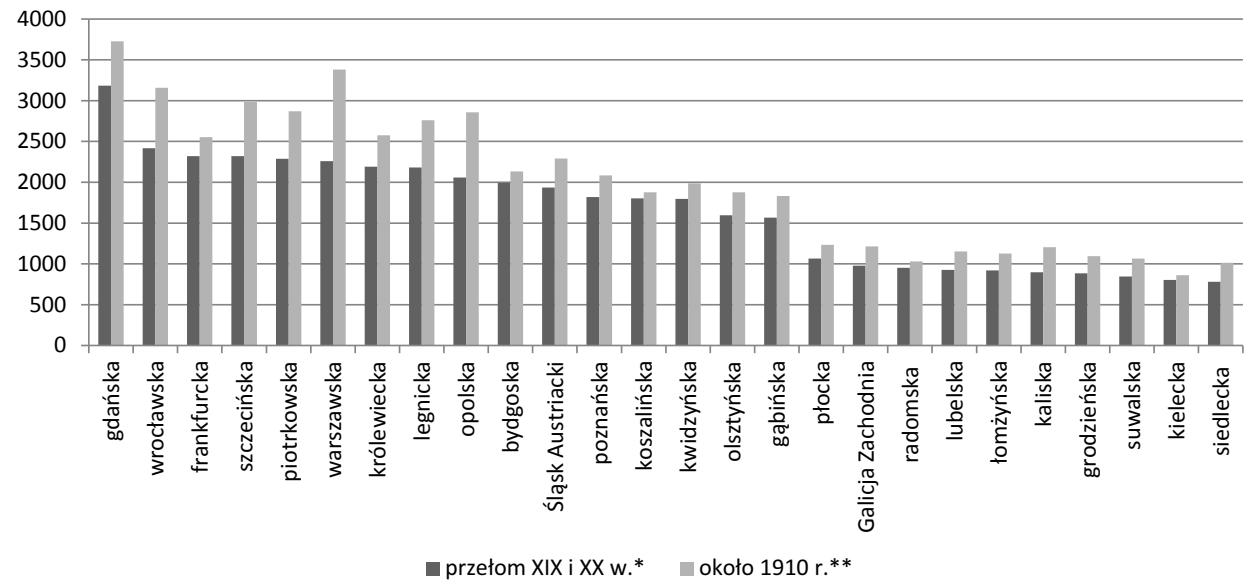

Legenda: * zabór rosyjski - 1897, zabór austriacki - 1900, ziemie na terenie Niemiec - 1895; ** zabór rosyjski - 1912, zabór austriacki - 1910, ziemie na terenie Niemiec - 1907.

Źródło: oprac. własne na podstawie szacunków regionalnego PKB; dane dla obszarów leżących we współczesnych granicach Polski zgodnie z opisem w podrozdz. „Zakres geograficzny badania”.

należącej do zaboru pruskiego (gdańskiej) oraz sześciu rejencji leżących na Ziemiach Zachodnich i Północnych (wszystkie rejencje ślasskie, szczecińska, królewiecka i frankfurcka). Około dziesięć lat później ich PKB per capita pozostawał najwyższy, chociaż niektóre z nich rozwijały się szybciej (rejencja opolska), gdy inne przeżywały wolniejszy wzrost gospodarczy (rejencje frankfurcka i szczecińska). W drugiej grupie znalazły się regiony, których PKB per capita pod koniec XIX w. zawierał się w przedziale pomiędzy 1500 a 2000 GK USD'1990. Były to wszystkie pozostałe rejencje z terenu ówczesnych Niemiec, zarówno z zaboru pruskiego, jak z Ziem Zachodnich i Północnych oraz Ślask Austriacki. W tej grupie nie znalazła się żadna gubernia z zaboru rosyjskiego. Wreszcie w ostatniej grupie znalazły się regiony, których poziom PKB per capita pod koniec XIX w. oscylował wokół 1000 GK USD'1990 (lub niżej). Sa to wszystkie gubernie zaboru rosyjskiego z wyjątkiem dwóch wyżej wspomnianych oraz Galicja Zachodnia. Podział na te trzy grupy utrzymał się w zasadzie do wybuchu I wojny światowej.

$\mathrm{Na}$ podstawie przedstawionych oszacowań można dostrzec regiony wyraźnie zacofane, należące do ostatniej z wymienionych grup, stanowiące zarazem zdecydowaną większość dwóch zaborów - rosyjskiego i austriackiego. Poziom PKB per capita w najzamożniejszej z tej grupy 
guberni płockiej stanowił pod koniec XIX w. zaledwie około 70\% PKB per capita najuboższej w drugiej grupie rejencji gąińskiej. Ta różnica pogłębiła się jeszcze w następnych latach, gdy poziom PKB per capita najzamożniejszej z trzeciej grupy Galicji Zachodniej stanowił ledwie 2/3 PKB per capita rejencji gąbińskiej.

$\mathrm{Na}$ podstawie przedstawionych danych PKB per capita oszacowaliśmy średnie roczne tempo wzrostu gospodarczego badanych obszarów. Pozwalają one ocenić dynamikę wzrostu poszczególnych regionów leżących w dzisiejszych granicach Polski oraz tempo rozwoju poszczególnych rejencji i guberni w pierwszym dziesięcioleciu XX w.

Wykres 5. Średni roczny wzrost PKB per capita obszarów tworzacych obecne terytorium Polski na przełomie XIX i XX w. oraz około 1910 r. (w tys. GK USD’1990)

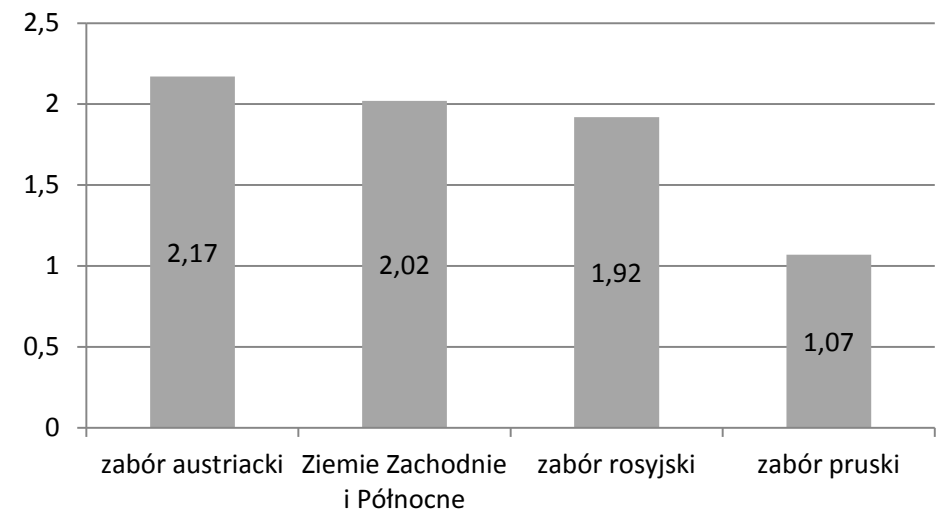

Źródło: oprac. własne na podstawie szacunków regionalnego PKB; dane dla obszarów leżących we współczesnych granicach Polski zgodnie z opisem w podrozdz. „Zakres geograficzny badania”. Dla zaboru rosyjskiego lata 1897-1912, dla zaboru austriackiego - 1900-1910, dla ziem znajdujacych się w granicach Niemiec - 1895-1907.

Na wykresie 5 zaprezentowano dynamikę wzrostu czterech głównych obszarów składających się na terytorium dzisiejszej Polski. Spośród nich najwyższe tempo wzrostu reprezentował zabór austriacki $(2,17 \%)$, co wydaje się nieco zaskakujące. Mogło to być spowodowane $\mathrm{z}$ jednej strony efektem niskiej bazy (bardzo niski poziom PKB per capita w 1900 r.), a z drugiej boomem naftowym w pierwszym dziesięcioleciu XX w., związanym z eksploatacją złóż karpackich. Drugie miejsce zajmuja Ziemie Zachodnie i Północne (1,99\%), na co przede wszystkim miał wpływ szybki wzrost gospodarczy wszystkich rejencji z prowincji śląskiej (zob. wykres 6). Niemal taką samą dynamikę miał zabór rosyjski (1,94\%), przy czym szybki wzrost tej części ziem polskich 
opierał się w znacznym stopniu na szybkim rozwoju guberni warszawskiej. Najsłabszą dynamikę wzrostu reprezentował zabór pruski, który mógł liczyć na wzrost na poziomie 1,07\%. Niższa dynamika wzrostu tego regionu była spowodowana jego rolniczym charakterem i niewielka liczbą dużych i uprzemysłowionych ośrodków miejskich (poza Gdańskiem i Poznaniem).

Wykres 6. Średni roczny wzrost PKB per capita według jednostek administracyjnych (guberni, rejencji) leżących we współczesnych granicach Polski (w \%)

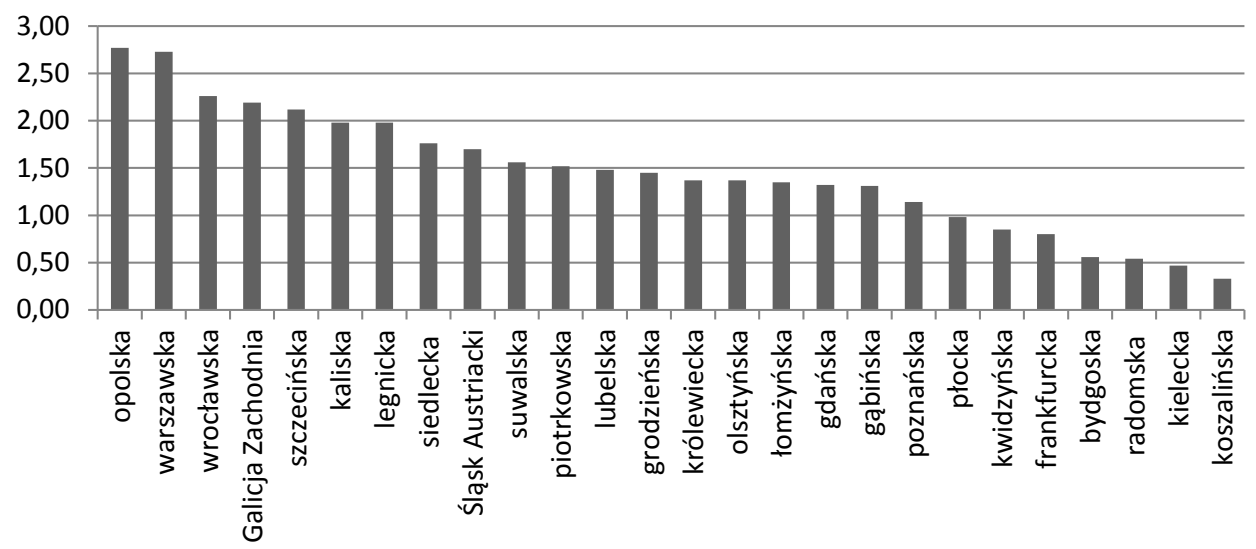

Źródło: oprac. własne na podstawie szacunków regionalnego PKB; dane dla obszarów leżących we współczesnych granicach Polski zgodnie z opisem w podrozdz. „Zakres geograficzny badania”. Dla zaboru rosyjskiego lata 1897-1912, dla zaboru austriackiego - 1900-1910, dla ziem znajdujących się w granicach Niemiec - 1895-1907.

Dane dotyczące poszczególnych jednostek administracyjnych (guberni, rejencji, prowincji) wskazuja, że z reguły szybko rozwijały się regiony juz dobrze rozwinięte i wysoko zurbanizowane (rejencje śląskie i szczecińska, gubernia warszawska). Jednak obok tych obszarów wysoki wzrost w okresie przed I wojną światową notowały również niektóre regiony o niskim PKB per capita i niewielkim uprzemysłowieniu, jak gubernia kaliska, a przede wszystkim wspomniana wyżej Galicja Zachodnia, która cieszyła się bardzo wysokim, ponad 2-procentowym wzrostem. Do pewnego stopnia może zaskakiwać dość wolny wzrost prowincji poznańskiej (do kwestii tej wrócimy dalej). Zwraca uwagę stosunkowo niska dynamika wzrostu uprzemysłowionej guberni piotrkowskiej (szczególnie w porównaniu z innymi centrami przemysłowymi). W tym ostatnim przypadku miały na to zapewne wpływ gwałtowne załamanie produkcji przemysłowej wywołane rewolucja $1905 \mathrm{r}$. oraz szybki przyrost populacji, jeden z najwyższych na ziemiach Królestwa Polskiego - ludność 
guberni w ciagu dwóch dekad poprzedzających wybuch wojny wzrosła o przeszło 40\%. Wartości PKB per capita i PKB dla wskazanych wyżej jednostek administracyjnych zawiera aneks.

Przedstawione oszacowania pozwalają zwrócić uwagę na kilka problemów rozwoju ziem polskich w okresie zaborów. Zastanawiają umiarkowane wyniki prowincji poznańskiej, czyli większości historycznej Wielkopolski, wiek wcześniej należącej do najlepiej rozwiniętych ziem Korony Królestwa Polskiego (a potem Księstwa Warszawskiego) ${ }^{56}$. U progu XX w. prowincja poznańska (rejencje bydgoska i poznańska) zaliczała się do najsłabiej rozwiniętych regionów Cesarstwa Niemieckiego, miała też niższy PKB per capita niż uprzemysłowione gubernie warszawska i piotrkowska. Można więc przyjąć, iż w warunkach dynamicznego wzrostu gospodarki Niemiec w ostatnich dekadach XIX w. rozwój ich wschodnich prowincji następował wolniej. Z drugiej strony prowincja poznańska była wyraźnie lepiej rozwinięta od wschodniej Wielkopolski leżącej w Królestwie Polskim (gubernia kaliska). Tereny te miały na początku XX w. poziom PKB aż o połowę niższy niż sąsiadujące powiaty prowincji poznańskiej. Na tak duże różnice mogły mieć wpływ zarówno uwarunkowania instytucjonalne i infrastrukturalne, jak i odmienne ścieżki rozwoju demograficznego, zwłaszcza emigracja wewnętrzna w ramach Cesarstwa Niemieckiego.

Koncentracja przemysłu Królestwa Polskiego w guberni warszawskiej i piotrkowskiej, skupiających zarazem kluczowe ośrodki przemysłowe Cesarstwa Rosyjskiego, spowodowała ich późny i nierównomierny, ale szybki wzrost w ostatnich dekadach XIX i na początku XX w. Miał on charakter wyspowy, dotyczył uprzemysłowionego okręgu łódzkiego i dąbrowskiego, a zajmujące znaczną część guberni obszary wiejskie pozostały słabo rozwinięte i niezurbanizowane. Gubernia warszawska rozwijała się dzięki dynamice metropolii warszawskiej jako centrum administracyjnego i usługowego oraz znaczącego ośrodka przemysłowego i węzła komunikacyjnego. Warszawa i Łódź pozostawały największymi miastami i to one wpływały na relatywnie wysoki poziom urbanizacji Królestwa Polskiego. Pozostałe miasta (z wyjątkiem Lublina) pozostały do początku XX w. co najwyżej ośrodkami średnich rozmiarów (większość miast liczyła po kilka tysięcy mieszkańców, jedynie miasta gubernialne sięgały 30-50 tys.) i nie odgrywały istotnej roli gospodarczej.

${ }^{56}$ U schyłku XVIII i na początku XIX w. poziom rozwoju tych ziem prawdopodobnie nie odstawał znacząco od Królestwa Prus, był natomiast wyższy niż ziem polskich pod władaniem Rosji i Austrii. 
Galicja była najludniejszą prowincją austriackiej części monarchii Habsburgów. Obejmowała z jednej strony względnie dobrze uprzemysłowione tereny przy granicy ze Ślaskiem oraz w okolicach Krakowa, a także wiele bardzo słabo rozwiniętych obszarów wiejskich. Ukształtowanie terenu oraz położenie geograficzne (łuk Karpat oddzielający region od ziem Austro-Węgier) pozostawały ważną bariera rozwoju. W efekcie, przy miernym zainteresowaniu państwa austriackiego regionem, procesy urbanizacji i industrializacji przebiegały powoli, a przeludnienie i ubóstwo wsi były trwałymi problemami. Szacunki PKB wskazują jednak, że Galicja Zachodnia jako całość była nieco „bogatsza” od najsłabiej rozwiniętych guberni Królestwa Polskiego. Badania Piotra Korysia i Macieja Tymińskiego ${ }^{57}$ pokazuja, że zróżnicowanie gospodarcze Galicji mierzone struktura zawodową było znikome, można więc przyjąć, że poziom rozwoju Galicji Zachodniej nie odbiegał istotnie od pozostałej części prowincji.

Na koniec naszych rozważań spróbujmy porównać wartości PKB per capita dla analizowanych regionów z szacunkami dla wysokorozwiniętych Wielkiej Brytanii i Niemiec oraz gorzej rozwiniętych Rosji i Węgier (zob. wykresy 7 i 8).

Wykres 7. PKB per capita poszczególnych regionów (guberni, rejencji) leżących we współczesnych granicach Polski, jako odsetek PKB per capita Niemiec i Wielkiej Brytanii w $1900 \mathrm{r}$.

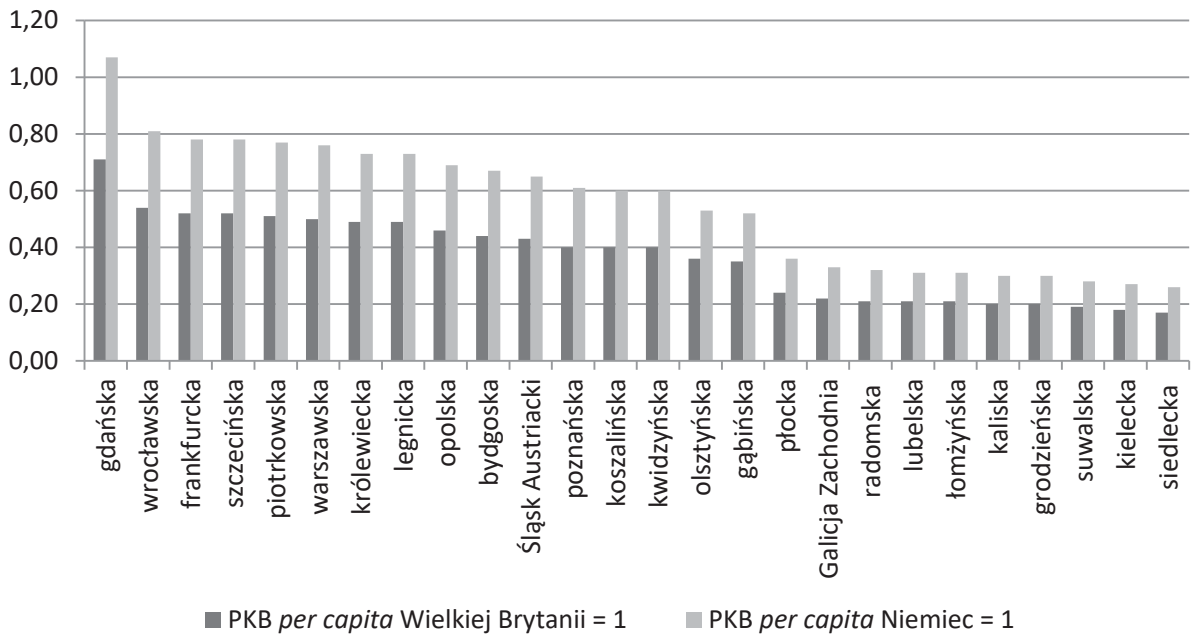

Źródło: oprac. własne na podstawie przeprowadzonych szacunków regionalnego PKB; dane dla innych krajów za: The Maddison-Project. The 2013 Version, http://www.ggdc.net/maddison/maddison-project/ home.html (15 V 2016).

${ }^{57}$ P. Koryś, M. Tymiński, Occupational... 
Wykres 8. PKB per capita poszczególnych regionów (guberni, rejencji) leżących we współczesnych granicach Polski, jako odsetek PKB per capita Rosji i Węgier w 1900 r.

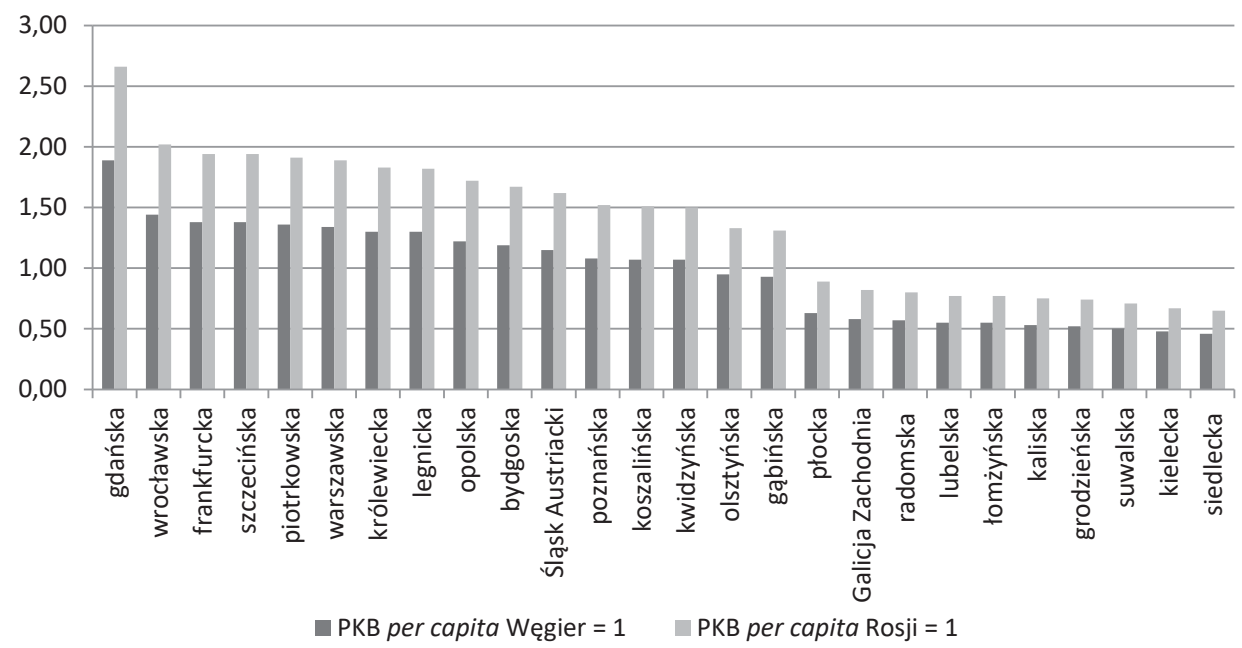

Źródło: oprac. własne na podstawie przeprowadzonych szacunków regionalnego PKB; dane dla innych krajów za: The Maddison-Project. The 2013 Version, http://www.ggdc.net/maddison/maddison-project/ home.html (15 V 2016).

Zaprezentowane dane wskazuja, że PKB per capita słabo rozwiniętych guberni Królestwa oraz Galicji był niższy od średniej rosyjskiej (dotyczą jej szacunki Paula Gregory'ego odnoszace się do 50 europejskich guberni Rosji, nie obejmuja one Królestwa). Zdecydowanie przewyższały ja gubernie warszawska i piotrkowska oraz wszystkie rejencje niemieckie. W porównaniu do PKB per capita Węgier większość terenów zaboru austriackiego (z wyjątkiem Śląska Austriackiego) i rosyjskiego (z wyjątkiem guberni piotrkowskiej i warszawskiej) legitymowała się niższym poziomem tego wskaźnika, podczas gdy terytoria znajdujące się pod rządami Niemiec miały z reguły wyższy produkt na głowę od węgierskiego bądź na podobnym poziomie.

Jeżeli idzie o średnią niemiecką spośród analizowanych regionów przekraczała ją tylko rejencja gdańska, poziom pozostałych rejencji (ale też guberni warszawskiej i piotrkowskiej) był niższy. W omawianym okresie wszystkie rejencje, poza opolska, rozwijały się wolniej niż Niemcy jako całość (dywergencja). Podobna sytuacja miała miejsce w przypadku guberni Królestwa: nawet dynamicznie „rosnąca” gubernia warszawska rozwijała się tylko w tempie zbliżonym do niemieckiej średniej. Co oczywiste, żaden z regionów nie zbliżył się do średniej brytyjskiej, „najlepsza” rejencja gdańska osiagała jedynie $70 \%$ tej wielkości. Dodajmy, że odstawały od niej także Niemcy jako całość, dane Angusa Maddisona pokazuja, że niemiecki PKB per capita stanowił w tym czasie około 
2/3 poziomu brytyjskiego. Pokazuje to wykres 9 , który ilustruje PKB per capita wszystkich ziem należących do Polski w dzisiejszych granicach $^{58}$ w porównaniu do Wielkiej Brytanii, Niemiec, Węgier i Rosji.

Wykres 9. PKB per capita Wielkiej Brytanii, Niemiec, Węgier, Polski i Rosji w 1900 i $1910 \mathrm{r}$.

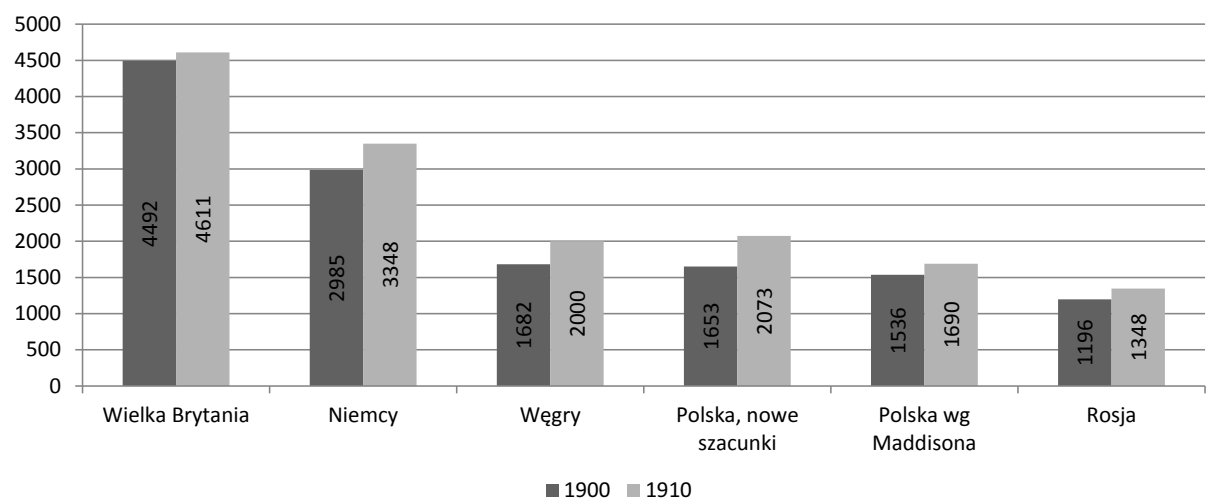

Źródło: oprac. własne; The Maddison-Project. The 2013 Version, http://www.ggdc.net/maddison/maddison-project/home.html (15 V 2016). PKB per capita Polski jest oszacowany dla danych z lat 1897 i 1912 dla zaboru rosyjskiego, 1900 i 1910 dla zaboru austriackiego oraz 1895 i 1907 dla ziem leżących na terenach Niemiec.

Powyższe dane wskazuja, że oszacowany przez nas polski PKB jest wyższy od wartości podanych przez Angusa Maddisona. Zdecydowanie też przewyższa wartości rosyjskiego PKB, a kształtuje się na podobnym poziomie do węgierskiego. W porównaniu do państw wysokorozwiniętych stanowi zarazem około $60 \%$ PKB niemieckiego i $45 \%$ brytyjskiego. $\mathrm{Na}$ podstawie tychże danych możemy pokusić się o konkluzję, że w analizowanym okresie nie dostrzegamy konwergencji PKB per capita między obszarem polskim i liderami w postaci Niemiec i Wielkiej Brytanii, jednocześnie możemy stwierdzić, że ziemie polskie rozwijały się w tempie podobnym do krajów Europy Środkowej (reprezentowanej tu przez Węgry) i nieco szybciej niż Rosja.

${ }^{58}$ Co jest oczywiście artefaktem, ani wtedy, ani nigdy wcześniej taki obszar nie funkcjonował jako jednolite terytorium. W badanym okresie dzielił się na wiele jednostek politycznych o odmiennych reżimach instytucjonalnych i poziomach rozwoju. Jest to jednak artefakt wygodny, pozwala bowiem spojrzeć wstecz na poziom gospodarki współczesnego terytorium Polski. Trzeba tu zarazem zaznaczyć, że przedstawione szacunki dla ziem polskich sa efektem zsumowania danych wykonanych dla różnych dat w każdym z zaborów, co było przede uzależnione od terminu sporządzenia spisów w Rosji, Austrii i Niemczech. Z tych względów dane dla całego terytorium dzisiejszej Polski należy traktować jedynie jako orientacyjne. 


\section{Wnioski}

Przedstawione w artykule szacunki regionalnego PKB ziem polskich u schyłku tzw. pierwszej globalizacji pozwalają na sformułowanie kilku konkluzji.

Najwyższa wartość PKB w granicach dzisiejszej Polski wytwarzały jednostki administracyjne o największym zaludnieniu i najsilniej uprzemysłowione: Królestwo Polskie (a w nim gubernie warszawska i piotrkowska) oraz tereny leżące w granicach Niemiec (w tym rejencje opolska i wrocławska). Szacunki PKB per capita wskazuja z kolei na ogromną różnicę w zamożności między Galicją a terenami znajdującymi się w ówczesnych granicach Niemiec, z Królestwem Polskim lokującym się po środku, w okolicy średniej dla całego analizowanego obszaru.

W badanym okresie największy wzrost PKB miał miejsce na ziemiach leżacych w granicach Rosji (o około 3/4), słabszy na obszarach zachodnich i północnych dzisiejszej Polski (o 40\%) i w zaborze austriackim (o 36\%). Spośród tych terenów najniższy wzrost produkcji globalnej zanotowały ziemie zaboru pruskiego (około 1/4). Z tego powodu, jeśli chodzi o całkowity PKB, dystans między Królestwem a obszarami leżącymi w granicach Niemiec uległ zmniejszeniu. Pamiętać jednak należy, że o ile obszary pod panowaniem Rosji i Austrii zamieszkane były głównie przez ludność polska, o tyle PKB Śląska czy Pomorza Zachodniego wytwarzała przede wszystkim ludność niemiecka (polskie osadnictwo dotyczyło jedynie części Górnego Śląska, Pomorza Środkowego oraz Warmii i Mazur).

Jeśli idzie o PKB per capita można mówić o daleko idącym zróżnicowaniu na linii wschód-zachód. Względnie wysoki jego poziom, porównywalny z niemieckim, osiagnęły jedynie gubernie warszawska i piotrkowska, koncentrujące większość produkcji przemysłowej Królestwa Polskiego. Tereny zaboru austriackiego zaliczyć należy w całości do słabo rozwiniętych. Najwyższy PKB per capita spośród analizowanych regionów uzyskiwały rejencje gdańska i wrocławska, jego poziom w pozostałych rejencjach niemieckich był średnio dwukrotnie wyższy od wartości dla Galicji czy guberni Królestwa (z wyjątkiem piotrkowskiej i warszawskiej).

Podsumowując, należy podkreślić, że nawet gwałtownie, choć wciąż wyspowo, przebiegające zjawiska urbanizacji i industrializacji ziem polskich nie zmieniły ich statusu. Pozostawały one na peryferiach nowoczesnej Europy. Wciąż słabo zurbanizowane, z bardzo dużym i nisko produktywnym sektorem rolnym, pozostające na peryferiach państw zaborczych, rozwijały się powoli, a dystans rozwojowy dostrzegalny na początku XIX w. przez całe stulecie nie uległ zmianom, a być może nawet się pogłębił. 


\section{Aneks}

PKB, PKB per capita i średnioroczny wzrost gospodarczy w jednostkach administracyjnych (guberniach, rejencjach) leżących we współczesnych granicach Polski, w 1900 i 1910 r.

\begin{tabular}{|c|c|c|c|c|c|}
\hline Obszar & $\begin{array}{c}\text { PKB (1900) } \\
\text { w mln GK } \\
\text { USD'1990 }\end{array}$ & $\begin{array}{c}\text { PKB (1910) } \\
\text { w mln GK } \\
\text { USD'1990 }\end{array}$ & $\begin{array}{c}\text { PKB per } \\
\text { capita } \\
(1900) \\
\text { W GK } \\
\text { USD'1990 }\end{array}$ & $\begin{array}{c}\text { PKB per } \\
\text { capita } \\
(1910) \\
\text { w GK } \\
\text { USD'1990 }\end{array}$ & $\begin{array}{c}\text { Średni } \\
\text { roczny } \\
\text { wzrost } \\
\text { PKB per } \\
\text { capita } \\
\text { 1900-1910 } \\
\text { w procen- } \\
\text { tach }\end{array}$ \\
\hline gubernia warszawska & 4166 & 8339 & 2258 & 3380 & 2,73 \\
\hline gubernia piotrkowska & 3176 & 5399 & 2287 & 2869 & 1,52 \\
\hline gubernia płocka & 571 & 870 & 1065 & 1232 & 0,98 \\
\hline gubernia lubelska & 1037 & 1697 & 925 & 1153 & 1,48 \\
\hline gubernia kaliska & 748 & 1401 & 897 & 1204 & 1,98 \\
\hline gubernia łomżyńska & 502 & 731 & 921 & 1127 & 1,35 \\
\hline gubernia grodzieńska & 460 & 711 & 883 & 1095 & 1,45 \\
\hline gubernia suwalska & 145 & 211 & 844 & 1064 & 1,56 \\
\hline gubernia radomska & 765 & 1094 & 951 & 1031 & 0,54 \\
\hline gubernia siedlecka & 590 & 976 & 779 & 1012 & 1,76 \\
\hline gubernia kielecka & 606 & 798 & 802 & 861 & 0,47 \\
\hline zabór rosyjski & 12765 & 22227 & 1376 & 1831 & 1,92 \\
\hline Śląsk Austriacki & 213 & 281 & 1935 & 2290 & 1,70 \\
\hline Galicja Zachodnia & 3359 & 4577 & 979 & 1215 & 2,19 \\
\hline zabór austriacki & 3572 & 4858 & 1008 & 1249 & 2,17 \\
\hline rejencja gdańska & 1943 & 2641 & 3183 & 3726 & 1,32 \\
\hline rejencja bydgoska & 1285 & 1528 & 1994 & 2131 & 0,56 \\
\hline rejencja poznańska & 2055 & 2600 & 1819 & 2083 & 1,14 \\
\hline rejencja kwidzyńska & 1541 & 1831 & 1795 & 1987 & 0,85 \\
\hline zabór pruski & 6824 & 8600 & 2104 & 2392 & 1,07 \\
\hline rejencja wrocławska & 3933 & 5639 & 2416 & 3159 & 2,26 \\
\hline rejencja opolska & 3425 & 5879 & 2058 & 2857 & 2,77 \\
\hline rejencja legnicka & 1827 & 2502 & 2181 & 2759 & 1,98 \\
\hline rejencja szczecińska & 1350 & 1917 & 2319 & 2982 & 2,12 \\
\hline rejencja królewiecka & 753 & 896 & 2190 & 2577 & 1,37 \\
\hline rejencja frankfurcka & 1474 & 1694 & 2321 & 2553 & 0,80 \\
\hline rejencja olsztyńska & 826 & 983 & 1595 & 1878 & 1,37 \\
\hline rejencja koszalińska & 1029 & 1139 & 1804 & 1878 & 0,33 \\
\hline rejencja gąbińska & 169 & 199 & 1567 & 1832 & 1,31 \\
\hline $\begin{array}{l}\text { Ziemie Północne } \\
\text { i Zachodnie }\end{array}$ & 14786 & 20848 & 2147 & 2728 & 2,02 \\
\hline
\end{tabular}

Źródło: oprac. własne. Metodologię i wykorzystane dane opisano w artykule. Dla zaboru rosyjskiego lata 1897 i 1912, dla zaboru austriackiego - 1900 i 1910, dla ziem znajdujacych się w granicach Niemiec - 1895 i 1907 . 


\section{Bibliografia}

Badia-Miró M., Guilera J., Lains P., Regional Incomes in Portugal. Industrialisation, Integration and Inequality, 1890-1980, „Revista de Historia Económica" 30, 2012, nr 2, s. 225-244.

Bjerke K., The National Product of Denmark 1870-1952, „The Review of Income and Wealth" 5, 1955, s. 123-151, http://www.roiw.org/1955_v.asp (10 IX 2016).

Broadberry S., Klein A., Aggregate and per capita GDP in Europe, 1870-2000. Continental, Regional and National Data with Changing Boundaries, $27 \mathrm{X}$ 2011, http://www.lse.ac.uk/economicHistory/pdf/Broadberry/EuroGDP2.pdf (5 VII 2016).

Caruana-Galicia P., German Regional GDP. Preliminary Land-Level LSE Estimates, 1871-1907, London 2011.

Caruana-Galicia P., Economic Development and Market Potential. European Regional Income Differentials, 1870-1913, London 2015, rozprawa doktorska, The London School of Economics and Political Science.

Clark C., The National Income, 1924-31, London 1932.

Crafts N.F.R., Regional GDP in Britain, 1871-1911. Some Estimates, „London School of Economics. Working Paper" 2004, nr 3.

Dederko B., Dochód społeczny Polski, „Kwartalnik Statystyczny” 1930, z. 2, s. $135-150$.

Electronic Repository of Russian Historical Statistics, $18^{\text {th }}-21^{\text {st }}$ centuries, http:// ristat.org/(16 IV 2016).

Enflo K., Henning M., Schön L., Swedish Regional GDP 1855-2000. Estimations and General Trends in the Swedish Regional System, „Research in Economic History" 30, 2014, s. 47-89.

Fenoaltea S., The Growth of the Italian Economy, 1861-1913. Preliminary Second-Generation Estimates, „European Review of Economic History” 2005, nr 9, s. 273-312.

Fenoaltea S., The Reconstruction of Historical National Accounts. The Case of Italy, „PSL Quarterly Review” 63, 2010, nr 252, s. 77-96.

Frank H., Regionale Entwicklungsdisparitäten im deutschen Industrialisierungsprozess 1849-1939. Eine empirisch-analytische Untersuchung, Hamburg 1995.

Geary F., Stark T., Examining Ireland's Post-Famine Economic Performance. The Distribution of Gross Domestic Product between the Countries of the United Kingdom, 1861-1911, „The Economic Journal” 2002, nr 112, s. 919-935.

Geary F., Stark T., Regional GDP in the UK, 1861-1911. New Estimates, „The Economic History Review" 68, 2015, nr 1, s. 123-144.

Good D.F., The Economic Lag of Central and Eastern Europe. Income Estimates for the Habsburg Successor States, 1870-1910, „Journal of Economic History" 1994, nr 54, s. 869-891.

Good D.F., Ma T., New Estimates of Income Levels in Central and Eastern Europe, 1870-1910, w: Von der Theorie zur Wirtschaftspolitik - ein Oester- 
reichischer Weg. Festschrift zum 65. Geburtstag von Erich Streissler, red. F. Baltzarek, F. Butschek, G. Tichy, Stuttgart 1998, s. 147-168. Gregory P., Russian National Income 1885-1913, Cambridge 1982.

Hoffmann W.G., Das Wachstum der Deutschen Wirtschaft Seit der Mitte des 19. Jahrhunderts, Berlin 1965.

Jelonek A., Ludność miast i osiedli typu miejskiego na ziemiach Polski od 1810 do 1960 r., Warszawa 1968 („Dokumentacja Geograficzna”, 3-4).

Kalecki M., Landau L., Szacunek dochodu spotecznego w r. 1929, Warszawa 1934.

Kalecki M., Landau L., Dochód społeczny w r. 1933 i podstawy badań periodycznych nad zróżnicowaniem dochodu, Warszawa 1935.

Koryś P., Tymiński M., Occupational Structure in the Polish Territories at the Turn of the 20 $0^{\text {th }}$ (1895-1900) century, „Working Papers from Faculty of Economic Sciences, University of Warsaw” 2015, nr 9.

Koryś P., Tymiński M., Struktura zawodowa ziem polskich na przełomie XIX $i X X w .$, RDSG, t. 75, 2015, s. 129-166.

Łukasiewicz J., Dynamika rozwoju przemystu na ziemiach polskich. Indeks produkcji przemysłowej w latach 1870-1913, w: Gospodarka przemysłowa $i$ poczatki cywilizacji technicznej $w$ rolniczych krajach Europy. Studia $i$ materiały, red. I. Pietrzak-Pawłowska, Wrocław 1977, s. 101-112.

Maddison A., The World Economy. Historical Statistics, Development Centre of the Organisation for Economic Co-operation and Development, 2006.

The Maddison-Project. The 2013 Version, http://www.ggdc.net/maddison/maddison-project/home.html (15 V 2016).

Malinowski M., Zmierzyć zacofanie. Zestawienie najważniejszych szacunków materialnych standardów życia w Polsce przedprzemysłowej, RDSG, t. 76, 2016, s. 61-91.

Markevich A., Economic Development of the late Russian Empire in a Regional Perspective, 2014, SSRN: http://ssrn.com/abstract=2555273 (12 V 2016).

Martínez Galarraga J., New Estimates of Regional GDP in Spain, 1860-1930, „Working Papers in Economics from Universitat de Barcelona. Recerca en Economia” 2007, nr 177.

Schulze M.-S., Reestimating Austrian GDP, 1870-1913. Methods and Sources, „Economic History Working Papers” 1997, nr 36.

Schulze M.-S., Origins of Catch-up Failure. Comparative Productivity Growth in the Habsburg Empire, 1870-1910, „European Review of Economic History" 2007, nr 11, s. 189-218.

Schulze M.-S., Regional Income Dispersion and Market Potential in the Late Nineteenth Century Hapsburg Empire, „Working Papers” 2007, nr 106.

Shaw-Taylor L., The Occupational Structure of England and Wales, c. 1750 -1911, Paper prepared for the INCHOS workshop held in Cambridge, 29-31VII 2009, http://www.geog.cam.ac.uk/research/projects/occupations/ britain19c/papers/paper5.pdf (1 VIII 2016).

Wójtowicz A., Wójtowicz G., Dlaczego nie jesteśmy bogaci? Dystans gospodarki polskiej do zachodnioeuropejskiej, Warszawa 2009.

Wójtowicz G., Trendy i ewolucja. Dzieje gospodarcze ziem polskich, Warszawa 2006. 
Maciej Bukowski, Piotr Koryś, Cecylia Leszczyńska, Maciej Tymiński

Regional development of the Polish lands under partitions. A comparison of the level of gross product per capita in the territories of modern Poland at the turn of the twentieth century (results of first estimations)

(Summary)

The problem of development of regional economies has been one of the most important in the present studies of history of economy. The present text aims to analyse the value of gross domestic product for the year of 1900 and 1910 of the regions that are located within the borders of modern Poland. On the basis of source data, the value of GDP, GDP per capita, and an economic growth rate for individual districts and gubernyias are estimated. The results have been used to conduct a comparative analysis of the development level of provinces incorporated to different partitioning powers. The highest economic grow rate at the turn of the twentieth century had the regions within the borders of the contemporary German Empire and two gubernyias of the Polish Kingdom - of Warsaw and Piotrków, while the level of production in the remaining regions (the Austrian and a major part of the Russian partition) indicates their deep economic underdevelopment.

Maciej Bukowski - dr, zatrudniony w Katedrze Historii Gospodarczej Wydziału Nauk Ekonomicznych Uniwersytetu Warszawskiego. Specjalizuje się w badaniach nad rozwojem gospodarczym Europy Środkowej z zastosowaniem metod ilościowych (ekonometrii, statystyki, kliometrii). Zainteresowania badawcze koncertuje na instytucjonalnych determinantach rozwoju gospodarczego, industrializacji i przekształceniu gospodarki przedindustrialnej w uprzemysłowiona, ze szczególnym uwzględnieniem przemian w strukturze zatrudnienia, PKB, produktywności.

Maciej Bukowski - PhD, Chair of Economic History of the Faculty of Economic Sciences, University of Warsaw. He specialises in research on the economic development of Central Europe with the use of quantitative methods (econometrics, statistics, cliometrics). His research interests focus on institutional determinants of economic development, industrialisation and transformation of pre-industrial economy into industrial one, with special emphasis on changes in the structure of employment, GDP, productivity.

E-mail: mbukowski@wne.uw.edu.pl.

Piotr Koryś - dr, zatrudniony w Katedrze Historii Gospodarczej Wydziału Nauk Ekonomicznych Uniwersytetu Warszawskiego. Zajmuje się badaniem 
modernizacji ziem polskich w perspektywie historycznej. Publikował m.in. w „Rocznikach Dziejów Społecznych i Gospodarczych”, „Dziejach Najnowszych” oraz „Ekonomii”. W 2016/2017 r. był visiting fellow w Instytucie Nauk o Człowieku w Wiedniu.

Piotr Koryś - PhD, Chair of Economic History of the Faculty of Economic Sciences, University of Warsaw. He conducts research into the modernisation of the Polish lands in a historical perspective. He has published, among others, in the following periodicals: Roczniki Dziejów Społecznych i Gospodarczych, Dzieje Najnowsze and Ekonomia. In 2016/2017 he was visiting fellow at the Institute for Human Sciences in Vienna.

E-mail: pkorys@wne.uw.edu.pl.

Cecylia Leszczyńska - dr hab., zatrudniona w Katedrze Historii Gospodarczej Wydziału Nauk Ekonomicznych Uniwersytetu Warszawskiego. Zainteresowania badawcze: historia gospodarcza XIX i XX w., w szczególności okres II Rzeczypospolitej. Specjalizuje się w badaniach dotyczacych historii systemów monetarnych, bankowości centralnej oraz statystyki historycznej. Jest autorem/współautorem monografii: Zarys historii polskiej bankowości centralnej, Warszawa 2010 (wersja ang.: An Outline History of Polish Central Banking, Warsaw 2011); Zarys historii Polski w liczbach: społeczeństwo, gospodarka, Warszawa 2012 (oprac. z: C. Kuklo, J. Łukasiewicz); Polska polityka pieniężna $i$ walutowa w latach 1924-1936. W systemie Gold Exchange Standard, Warszawa 2013; Polska w Europie/Poland in Europe, Warszawa 2014 (z: C. Kuklo, J. Łukasiewicz).

Cecylia Leszczyńska - Dr Hab., Chair of Economic History of the Faculty of Economic Sciences, University of Warsaw. Research interests: $19^{\text {th }}$ and $20^{\text {th }}$ century economic history, especially the period of the Second Republic of Poland; she specialises in studies on the history of Polish central banking, monetary system, and historical statistics. She is the author/co-author of: Zarys historii polskiej bankowości centralnej, Warsaw, 2010 (An Outline History of Polish Central Banking, Warsaw, 2011); Zarys historii Polski w liczbach: społeczeństwo, gospodarka, Warsaw, 2012 (ed. with: C. Kuklo, J. Łukasiewicz); Polska polityka pieniężna $i$ walutowa w latach 1924-1936. W systemie Gold Exchange Standard, Warsaw, 2013; Polska w Europie/Poland in Europe, Warsaw, 2014 (with: C. Kuklo, J. Łukasiewicz).

E-mail:cleszczynska@wne.uw.edu.pl.

Maciej Tymiński - absolwent historii, archeologii śródziemnomorskiej i ekonomii, dr hab. nauk ekonomicznych, kierownik Katedry Historii Gospodarczej Wydziału Nauk Ekonomicznych UW oraz kierownik Ośrodka Badań Ekonomicznych Instytutu Studiów Społecznych UW. Zainteresowania badawcze: historia gospodarcza czasów komunizmu w Polsce, przede wszystkim znaczenie 
aparatu partyjnego w gospodarce, problem rozwoju ziem polskich w XIX i XX w., wpływ zmian instytucjonalnych na zachowania społeczne w gospodarce. Autor monografii Partyjni agenci. Analiza instytucjonalna działalności lokalnych instancji PZPR w przemyśle (1949-1955), Warszawa 2011.

Maciej Tymiński - Dr Hab., graduate of history, Mediterranean archaeology and economics, associate professor in economics; head of the Chair of Economic History of the Faculty of Economic Sciences, University of Warsaw, and of the Centre for Economic Research at the Robert B. Zajonc Institute for Social Studies, University of Warsaw. His research interests include: economic history of Poland in the communist period, especially the importance of the party apparatus for the economy, the development of Polish lands in the $19^{\text {th }}$ and $20^{\text {th }}$ century, the impact of institutional changes on social behaviour in economy. The author of a monograph: Partyjni agenci. Analiza instytucjonalna działalności lokalnych instancji PZPR w przemyśle (1949-1955), Warsaw, 2011. E-mail: mtyminski@wne.uw.edu.pl. 